\title{
4. Performing America: Featherwork and Affective Politics
}

\author{
Ulinka Rublack
}

\begin{abstract}
This article analyses feather-work as central material in the culture of a German court around 1600 . Materials afforded meanings, invited specific practices, and thus became agents that "enmeshed" an audience to endorse new social, economic, and political norms. They formed part of an affective culture and habitus, reproduced in similar spaces and atmospheres. Feathers could be part of specific emotional styles and embodied practices. Their appreciation intertwined with specific collecting and media strategies as well as the encounter of the Americas. Artefacts fostered emotional communication and aimed at affective transformation in performances such as those at the Württemberg court. They strongly appealed to tactile sensory engagement as much as to vision as modes of perception.
\end{abstract}

Keywords: Protestant court culture; feathers as artefacts; cultural translation; material culture and the Thirty Years' War; Frederick I of Württemberg

\section{Animated Accessory}

In 1895, Aby Warburg published an article on theatre costume and the beginning of opera at the Medici court. Among the art historian's most interesting finds was a tailor's account book for costumes to stage the famous musical intermezzi during festivities in honour of Christina of Lorraine in $1589 .{ }^{1}$ Two master tailors

1 These intermezzi were staged in-between scenes of the comedy La Pellegrina and their success enabled opera to emerge as an independent genre. Aby Warburg, "Die Theaterkostüme für die Intermedien," in Aby

Burghartz, S., L. Burkart, C. Göttler, U. Rublack, Materialized Identities in Early Modern Culture, 1450-1750: Objects, Affects, Effects. Amsterdam: Amsterdam University Press, 2021 DOI 10.5117/9789463728959_CHO4 
and fifty apprentices had created 286 costumes. The account book noted fabrics and materials for each scene, as well as negotiations about props in relation to their cost. ${ }^{2}$ One decision concerned fifteen sirens, who prominently featured as bird-like creatures endowed with the power of song. Creating their upper garments from real feathers was deemed far too extravagant; instead, canvas was ordered onto which the feathers were painted and then cut out. Finally, these painted feathers were individually glued onto the costumes and assembled alongside papier-mâché breasts and other accessories to create characters. Warburg stressed that account books make for "dry" source material. Yet they indicated the "intensity" of an ambition to create "living memory images" - lebendige Erinnerungsbilder - of the classical age in Florence. These facilitated an emotionally resonant dialogue between antiquity and the present.

This chapter follows Warburg's interest in court festivities and the emotional power of accessories. It analyses the role of featherwork in the 1599 staging of Duke Frederick of Württemberg as "Lady America" as well as the Protestant Union festivals of his son John Frederick. Account books reveal the importance of feather-crafting at this early modern court in Stuttgart, the capital of a land-locked territory in the south-west of Germany. Feather-crafting has long been overlooked as a trade that grew and substantially diversified during the sixteenth century. European interest in Latin-American featherwork has attracted much scholarly attention. Yet the remarkable sixteenth-century diversification of European "be-feathered" head-wear complemented this fascination. ${ }^{3}$ Courts had initially provided a milieu for which noblemen commissioned highly innovative ensembles of dyed ostrich feathers on helmets to compete in tournaments. ${ }^{4}$ By the late sixteenth century, the greater availability of exotic feathers made references to the encounter with the Americas possible in entertainments; however, much like advanced embroidery, the production

Warburg: Werke in einem Band, ed. Martin Trend, Sigrid Weigel, and Perdita Ludwig (Frankfurt-am-Main: Suhrkamp, 2010), 124-167, and his better-known "Sandro Botticellis 'Geburt der Venus' und 'Frühling'," in ibid., 32-38; see also Horst Bredekamp, Image Acts: A Systematic Approach to Visual Agency (Berlin and Boston, MA: De Gruyter, 2018), 253-264.

2 Warburg, "Theaterkostüme," 135.

3 For a recent, major volume on American featherwork see Alessandra Russo, Gerhard Wolf, and Diana Fane, eds., Images Take Flight: Feather Art in Mexico and Europe, 1400-1700 (Munich: Hirmer, 2015). See also Mariana Françozo, "Beyond the Kunstkammer: Brazilian Featherwork in Early Modern Europe," in The Global Lives of Things: Material Culture of Connections in the Early Modern World, eds. Anne Gerritsen and Giorgio Riello (London: Routledge, 2016), 105-127, and for the following see Ulinka Rublack, "Befeathering the European: The Matter of Feathers in the Material Renaissance," The American Historical Review 126, no. 1 (March 2021): 19-53, https://doi.org/10.1093/ahr/rhaboo6, and Stefan Hanß's chapter in this volume. 4 Carnival displays in cities like Nuremberg during the 1520 s and 1530 s experimented with costumes which used layers of cheap silks to imitate parrot feathers, or attached peacock feathers, Hans-Ulrich Roller, Der Nürnberger Schembartlauf: Studien zum Fest- und Maskenwesen des späten Mittelalters (Tübingen: Tübinger Vereinigung für Volkskunde, 1965), 71, 62. 
of intricate feather garments remained costly as well as technically, mentally, and physically extremely demanding. An engagement with such soft, light material required fine motor skills, manual dexterity, and great care, especially when it was sewn or glued. Yet, as Stefan Hanß's contribution in this volume shows, this challenge as well as the graphics, translucency, and movement of feathers made such artefacts enchanting. Their properties and demands on craftsmanship were seen to stimulate subtlety and the imagination. ${ }^{5}$

The 1599 Württemberg spectacle stands out as one of the most original of its time. It used the largest amount of exotic featherwork Europeans had ever seen, was generously funded by the court, and was staged publicly. There was, in other words, an exceptional investment in the use of exotic feathers to achieve mimetic faithfulness. Strikingly, the Württemberg entertainment did not represent America as simple or as inferior to Europe. It has thus previously been discussed - by those interested in early images of America, in the collecting of Americana, and in courtly culture - to the degree that the extant costume drawings for the performance are frequently reproduced. Elke Bujok has demonstrated that Jakob Frischlin's printed report of the occasion allows us to contextualize the images. They were inspired by John White's recent drawings that accompanied Thomas Harriot's travelogue to Virginia, published by Theodor de Bry. ${ }^{6}$ Historians of Württemberg, moreover, have established the immediate political context in which the event needs to be situated as a ritual of power. After prolonged diplomatic relations, Frederick had signed a treaty with Emperor Rudolf II in late January 1599 which, in return for a payment of 400,000 florins, liberated his duchy from its vassalage of Habsburg Austria. This ensured the continuity of the house of Württemberg and Lutheranism. Frederick now relied on his estates to pay this enormous sum. Predictably, the estates proved reluctant. They instantly assembled in Stuttgart in February 1599 and remained in the capital during carnival. Frederick used the licence of a carnival entertainment to demonstrate ducal strength and expectations for the duchy's brilliant future (Figs. 4.1 and 4.2.).

Yet we still need to explain why this duke chose to present an image of America and why featherwork should have been even more prominent in the Württemberg

5 See Rublack, "Befeathering the European" and Stefan Hanß's chapter in this volume.

6 Elke Bujok, Neue Welten in europäischen Sammlungen: Africana und Americana in Kunstkammern bis 1670 (Berlin: Reimer, 2004), 14. A digitalized original of the entire description of the tournament and festivities is available: Jakob Frischlin, Beschreibung deß fürstlichen Apparatus, königlichen Auffzugs, heroischen Ingressus und herrlicher Pomp und Solennittet (Frankfurt-am-Main: Joachim Brathering, 1602), 44, http://digital.slub-dresden.de/werkansicht/dlf/65017/1/.

7 For this important contextualization see Sabine Hesse, "Die Neue Welt in Stuttgart: Die Kunstkammer Herzog Friedrich I. und der Aufzug zum Ringrennen am 25. Februar 1599," in Hofkultur um 16oo: Die Hofmusik Herzog Friedrichs I. von Württemberg und ihr kulturelles Umfeld, ed. Joachim Kremer, Sönke Lorenz, and Peter Rückert (Sigmaringen: Thorbecke, 2010), 150-164. 
entertainment than in de Bry's images. As in the case of Florence, account books of craftspeople employed at the Württemberg court detail information of expenditure on featherwork, which has not been analysed in relation to the spectacle. In contrast to the Florentine tailor's records, these suggest that real and costly exotic feathers were used to recreate cloaks, headdresses, and skirts and that they were used alongside authentic artefacts from the Americas. This mimesis of American featherwork facilitated "translational technologies," as feather-workers would have needed to learn to work with exotic feathers, to cut, layer, and assemble them, and to imitate the colour intensity of exotic feathers through dyes. Exquisite stage images (see Figs. 4.1, 4.4-4.7, and 4.9-4.10) likewise underline the importance given to the event and the creation of what I call a "present image," a Jetzt-bild, of a contemporary culture across the Atlantic, rather than a memory image of antiquity.

I draw on Frischlin's report, the stage images, account books, and a broader view of Duke Frederick's reign to argue that the 1599 entertainment should not just be understood in response to the immediate political context of the Treaty of Prague, in which case its subject would have been incidental. Rather, the adaptation of new imagery and information about the New World served as cultural material to propagate a far wider vision of his politics. It advertised the benefits of stateled innovation, knowledge-making, trade, and cultural exchange. It conjured up curiosity and optimism in regard to the future, rather than aesthetic austerity, melancholy, and the apocalyptic fear with which Protestantism is so often equated. The entertainment, in sum, was designed to help enshrine Stuttgart's position among the culturally leading, forward-looking European courts. Feathers as specific materials were integral to how court spectacles were made to function. ${ }^{8}$ They served to make the display persuasive, and hence, in contemporary understandings, alive,

8 For the importance of rhetorical traditions to furnish ideas of aliveness and affect as signs of successful, persuasive art see Caroline van Eck, Classical Rhetoric and the Visual Arts in Early Modern Europe (Cambridge: Cambridge University Press, 2007). In 1550, by contrast, the astonishing staging of a Tupinambá village and battle in Rouen to welcome King Henry II had involved fifty Brazilian natives and 250 local sailors and prostitutes enacting them. Yet the use of accessories had been minimal. Startlingly, therefore, the French actors appeared naked or, perhaps more likely, were dressed in nude costumes, although body paint was used on some figures while the native Tupi could use basic headdresses. This decision may have been related to the expense of costumes, which were financed locally, but which amplified the message. Natural simplicity was contrasted to the wrong kind of ostentatiousness and dissimulation in France, see Michael Wintroub, A Savage Mirror: Power, Identity, and Knowledge in Early Modern France (Stanford, CA: Stanford University Press, 2006), 182; Amy Buono, "Representing the Tupinambá and the Brazilwood Trade in Sixteenth-Century Rouen," in Cultural Exchange between Brazil and France, ed. Regina R. Felix and Scott D. Juall (West Lafayette, IN: Purdue University Press, 2016), 29f. For Buono's argument that the Stuttgart entertainment does stereotype otherness for political purposes see Amy J. Buono, "Their Treasures Are the Feathers of Birds': Tupinambá Featherwork and the Image of America," in Images Take Flight: Feather Art in Mexico and Europe 1400-1700, ed. Alessandra Russo, Gerhard Wolf, and Diane Fane (Munich: Hirmer, 2015), 178-189. 
energizing, and emotionally powerful. The Stuttgart entertainment and a focus on featherwork, therefore, allow us to reflect on the importance of accessories in relation to the encounter with the Americas, which, as a new generation of scholars have shown, was as crucial for the period as its fascination with antiquity. ${ }^{9}$ A combination of textual and artefact-led methodologies can be used to explore how past people responded to a particular material, what kinds of energy they invested in an object, why they did so, and what emotions it might have evoked. ${ }^{10}$ This enables us to address continuities in the visual and rhetorical construction of affective atmospheres through one of the most fragile and delicate objects to be found in the early modern world.

\section{Staging America}

One cold morning in February 1599, over six thousand spectators gathered in the German town of Stuttgart to witness an extraordinary spectacle. It was carnival time, and the duke of Württemberg staged an entertainment that included many of his most respected councillors and officials. As the usual tournaments progressed, Duke Frederick I (1557-1608) led an elaborate, expensive, and meticulously planned procession in which he himself personified Lady America. This was the stately as much as playful manner in which drummers and trumpeters orchestrated the duke's arrival and his transformation into a woman. ${ }^{11}$

In his 1602 report of the event, the court historian and poet Jakob Frischlin highlighted the authenticity of the artefacts, which bore out the considerable investment in the event: Duke Frederick had shown himself in "form, figure, adornment and dress like the queen of America, with naked people, large clubs and clothes from parrots and many colours, none of which had been presented or seen in Swabia." ${ }^{\text {212 }}$ America was carried below a canopy to display her "gracefully"

9 For the Medici court see Lia Markey, Imagining the Americas in Medici Florence (University Park, PA: Pennsylvania State University Press, 2016).

10 The efforts invested in creating scenes and personifying figures attempted to do more than merely depict Indians as "dark strangers whose foreignness was amplified [...] by feathers and reinforced by a parrot." See Elizabeth Hill Boone's discussion of Christoph Weiditz's costume images in her "Seeking Indianness: Christoph Weiditz, the Aztecs and Feathered Amerindians," Colonial American Review 26, no. 1 (2017): 49 .

11 "[...] / Pomp/ pim/ pom/ Duke Frederick arrives/ pom/ pim/ pom/ duke Frederick/ Frederick/ Frederick arrives/ he arrives/ he arrives/ America arrives/ arrives/ she arrives/ America arrives/ the queen/ queen/ queen arrives/ she arrives/arrives/ the pimperle pom/the pimperle pom/ pom/ pom/ pom/Vide pomp/ Vide pom/ aso," Bujok, Neue Welten, 44.

12 Ibid., 14; Frischlin, Auffzug, 44. Frischlin's text would have addressed an upper-German audience which by now was extremely knowledgeable about different varieties of Latin American parrots, while 
hanging breasts. Gold pieces had been glued to the nude costume and "shone from afar," just like the crown of blue, green, and red parrot feathers. ${ }^{13}$ Frederick's entertainment was thus markedly different from other court masques - for instance, an "Indian Invention" in Dresden, in which ostrich and parrot feathers were simply attached to European clothing. ${ }^{14}$ As the representation of other nations became one of the most popular features of courtly "shews," the use of authentic costume distinguished aspiring rulers who revealed their true knowledge of other worlds. Stuttgart excelled in producing such costume - although the image produced in connection with the event depicted the duke himself adorned with body-paint and fabric rather than feathers. Both the text and the images produced independent, if overlapping, visual worlds, and it is now impossible to verify whether these images or Frischlin's text were more authentic, as the account of Frederick's attire presents one of several discrepancies. The account books record that Hans Karg, one of the ducal painters, received the considerable sum of 20 florins to document the entertainment on parchment. ${ }^{15}$ Karg had previously been sent out by the duke to record entertainments elsewhere, such as one at a Fugger wedding in $1591 .{ }^{16} \mathrm{He}$ was, therefore, a valued specialist. This evidence matches the high quality of these surviving, brightly coloured watercolours with tempera and extensive gilding, which named each depicted figure. ${ }^{17}$ The images might well have been shared with other courts.

The visual representation of Frederick was certainly inspired by de Bry's image of the Queen of Florida on the title page of the second volume, printed in 1591, as well as in an enlarged version inside the volume (Fig. 4.2). It depicted her on a throne decorated with fresh, green leaves (Maiengrün), followed by the most

Iberia in this respect had lost its "monopoly of mediating information about the New World and the Old," Renate Pieper, Die Vermittlung einer Neuen Welt: Amerika im nachrichtennetz des Habsburgischen Imperiums 1493-1598 (Mainz: von Zabern, 2000), 271.

13 Bujok, Neue Welten, 18; Frischlin, Auffzug, 50.

14 Claudia Schnitzer, Höfische Maskeraden:Funktion und Ausstattung von Verkleidungsdivertissements an deutschen Höfen der frühen Neuzeit (Tübingen: Niemeyer, 1999), 340.

15 HStAS, A 256, vol. 86, 383v, 384r: "von Ainem Auffzug, so Anno 1599 Im Thiergarten gehalten worden uf pergament zuverfertigen zalt."

16 Werner Fleischhauer, Renaissance im Herzogtum Württemberg (Stuttgart: Kohlhammer, 1971), 96; on Karg see also p. 169. On the Fugger's interest to maintain Augsburg's rank through magnificent displays at weddings and courtly tournaments see Julian Jachmann, "[...] in Ritterspieln und hohem Gebreng fremder nationen erfahren: Feste und Turniere der Fugger im frühneuzeitlichen Augsburg," in Herrschaft - Architektur - Raum: Festschrift für Ulrich Schütte zum 6o. Geburtstag, ed. Stephanie Hahn and Michael H. Sprenger (Berlin: Lukas Verlag, 2008), 261-275.

17 On the other hand, these images were executed on white paper rather than parchment, the writing appears hasty, and Bujok has, therefore, argued that these must have been preparatory stage sketches. If that is true, Karg's images would have been still more refined and are now lost. See Bujok, Neue Welten, 151, for a detailed description of their appearance now and changes. 


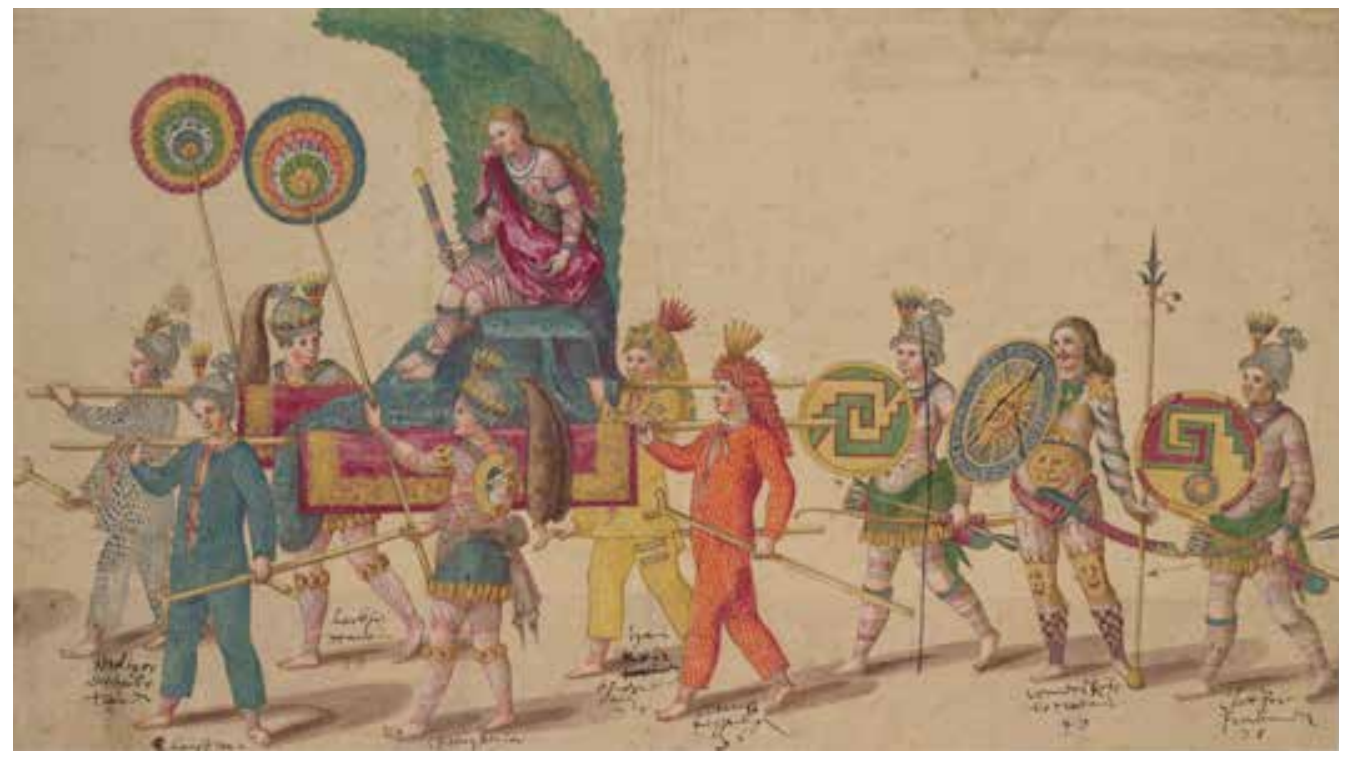

Figure 4.1: Procession at the Württemberg Court in Stuttgart, 1599: The sixth scene with Duke Frederick as Lady America. Watercolour, pigment, and gold on paper, $29.9 \times 53.3 \mathrm{~cm}$. Weimar, Graphische Sammlungen, Klassik Stiftung Weimar, inv. no. KK 207. Image @ Stiftung Weimarer Klassik und Kunstsammlungen/Museen. Photo: Roland Dreßler.

beautiful virgins decorated with pearls. ${ }^{18}$ Yet the watercolour image also suggests that Frederick was surrounded by men clad in featherwork and that the Aztec shields represented particularly prestigious artefacts. ${ }^{19}$ Featherwork was hence staged as artefact that instantiated an authentic experience of America as an equal sister and became even more important in Frischlin's literary commemoration of the event.

The Mexican feather shields were exquisite rarities and two of them survive to this day. ${ }^{20}$ Their complex crafting reveals that they were either pre-Columbian

18 Ibid., $15^{2-157}$, for a table which details references to de Bry. De Bry also inspired a much smaller staging of America at the Kassel court in 1596, and Bujok points out how it differed from the 1599 Stuttgart entertainment (pp. 157-159). For a discussion of the entertainment in relation to the de Bry depictions see also Maike Christadler, "Indigenous Skins: Indian Costume at the Court of Württemberg," in Visual Representations of Native Americans: Transnational Contexts and Perspectives, ed. Karsten Fritz (Heidelberg: Universitätsverlag, 2012), 13-28; Hesse, Kunstkammer, 159-161.

19 See the seminal comparative discussion in Helen Watanabe-O'Kelly, Triumphall Shews: Tournaments at German-Speaking Courts in their European Context, 1560-1730 (Berlin: Mann Verlag, 1992), 51 and Schnitzer, Höfische Maskeraden.

20 Die Kunstkammer der Herzöge von Württemberg: Bestand - Geschichte - Kontext, 3 vols., exh. cat. (Ulm: Jan Thorbecke, 2017), 1:164-171; Bujok presents a nuanced discussion of the complicated story of their precise provenance, see Bujok, Neue Welten, 112-114. These are extremely rare; only four of them are still extant, see also Hesse, Kunstkammer, 147f.; for a conservation report see Melanie Korn, Die zwei Federschilde des Landesmuseums Württemberg (Stuttgart, April 2015, unpublished thesis, with thanks 


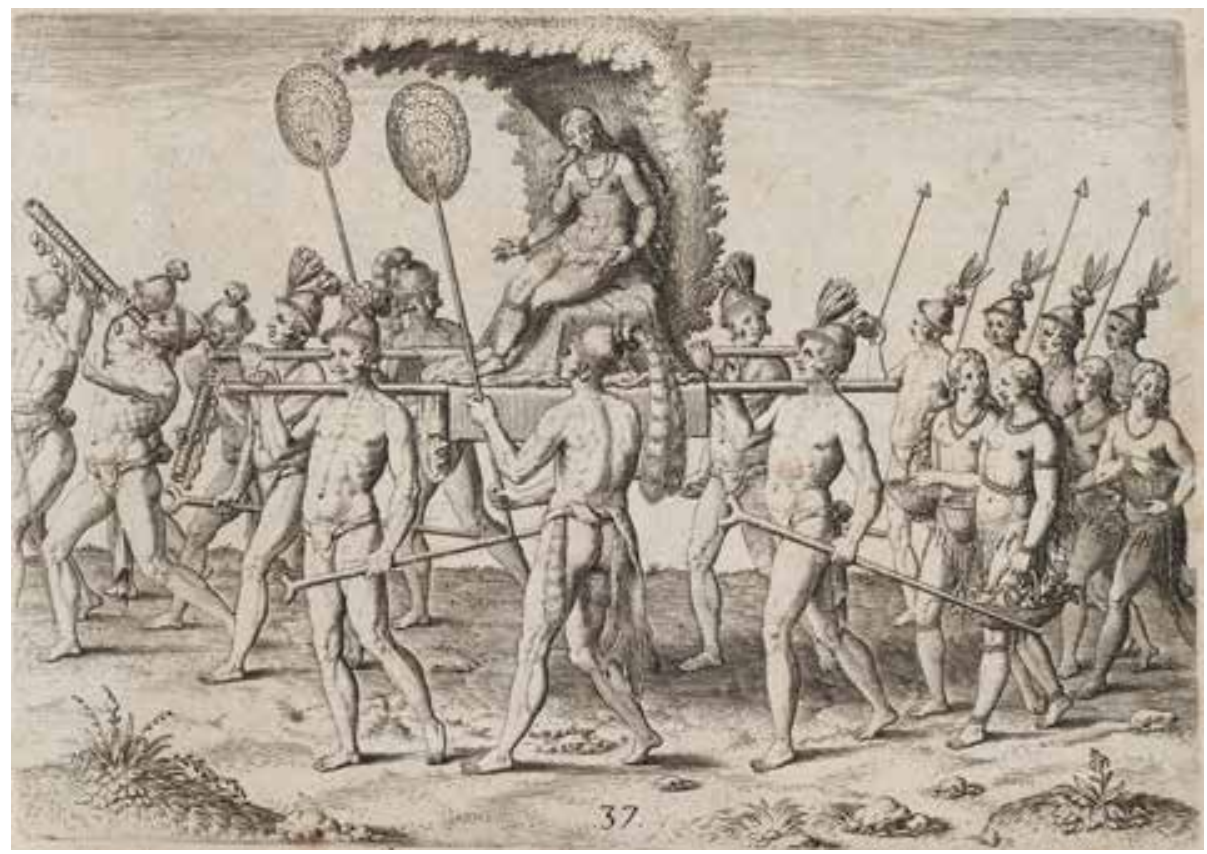

Figure 4.2: Theodor de Bry after Jacques le Moyne de Morgues, The queen-elect is brought to the king. Engraving. In Theodor de Bry, Der ander Theyl, der newlich erfundenen Landtschafft Americæ, Frankfurt am Main: Johann Feyerabendt, 1591, Plate XXXVII. Universitäts-Bibliothek Heidelberg. Image @ UniversitätsBibliothek Heidelberg.

or made shortly after the Spanish conquest (Fig. 4.3). About 250 reed sticks were connected with two types of plant fibre to serve as a foundation that was secured with leather and wood. Up to eight tiny, vibrantly coloured yellow or red feathers were then skilfully looped with plant fibre around its shaft and tied to two threads, which were sewn to dyed parts of the leather skin. In the centre of the shields, several layers of tiny, gathered feathers in five colours were glued to the foundation so as to compose a striking geometrical pattern of great intricacy. Geometrical patterns on shields would have impressed Europeans as a mathematically conceived, regular, and thus harmonious design. Their making required planning and patience - it was instantly recognizable as a civilizational achievement.

Three beautifully dressed, "courageous" men on horseback led the entertainment to represent Europe. Junker Philip von Lamersheym and Carl Egen, two prominent

to the author for making this available). This close engagement with making can suggest periodizations problematized by Alessandra Russo with reference to the Stuttgart shields in her article "Cortés's Objects and the Idea of New Spain: Inventories as Spatial Narratives," Journal of the History of Collections 23, no. 2 (2011): 246 . 


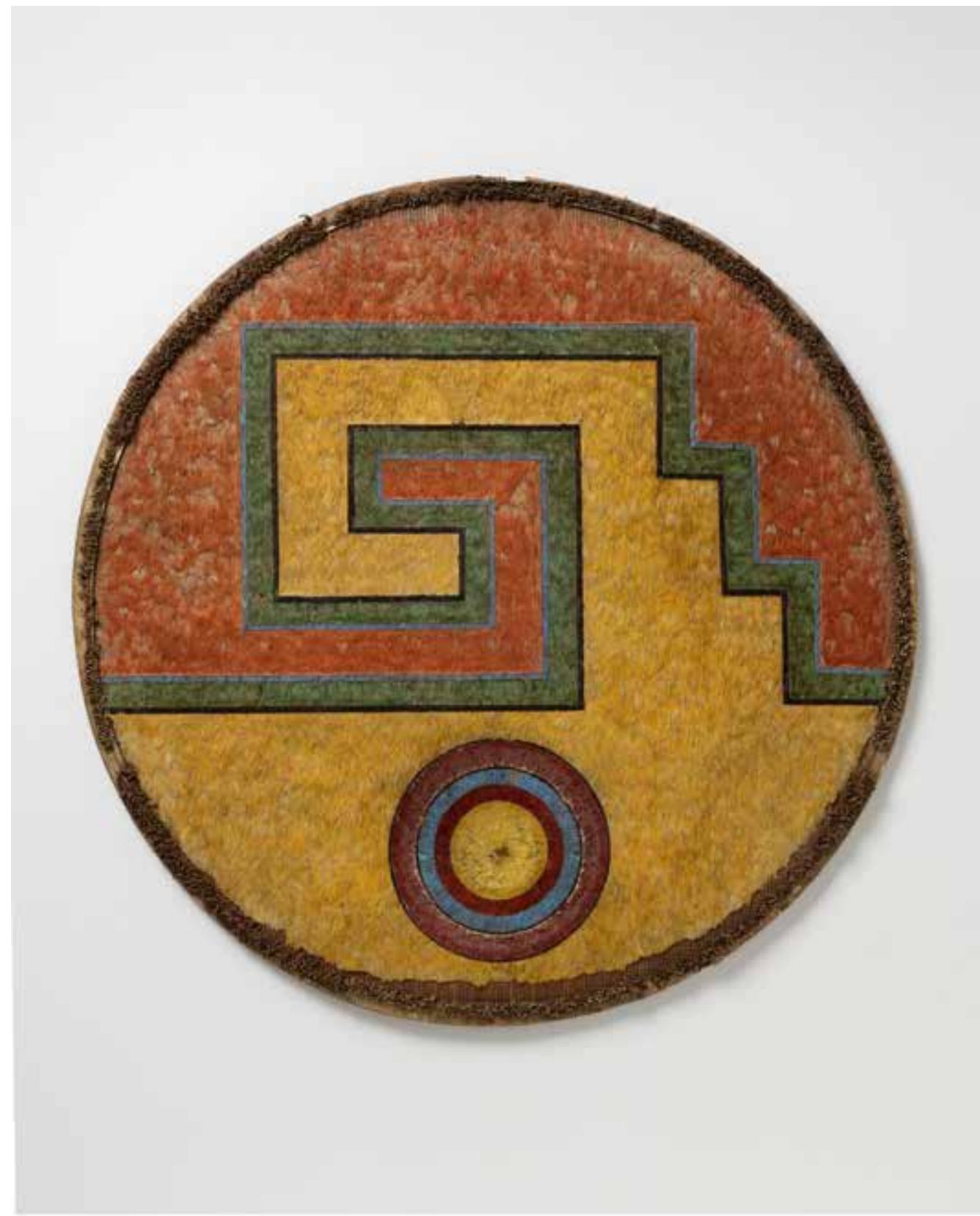

Figure 4.3: Red and Yellow Feather Aztec / Mexica Warrior Shield. Stuttgart, Landesmuseum. Image $\odot$ Landesmuseum Württemberg, Hendrik Zwietasch. 
courtiers, personified Columbus (d. 1506) and Vespucci (d. 1512), whose "shadow," Frischlin wrote, was still felt in Württemberg. They were described as experienced "pilots" to accompany America as she travelled to her sister Europe. In order to emphasize their familiarity with and interest in America, both men, according to Frischlin's text, had been clad with feather cloaks, though here there is a further discrepancy between the preparatory stage images. Frischlin highlighted the strong visual impact of the red, blue, yellow, and light-grey shades of parrot feathers:

Their cloaks were of a motley hue/

Much like a parrot/

Striped red and blue/

Thereafter yellow and pale grey too. Verily it looked passing fair/

As these two walked forward through the air.

Ihr Mäntel waren mancherley/

Von Farben/

als von papengäy/

Rot Striemen uberzwerch/

und blaw/

Darnach auch gelb/

und dann Liechtgraw. Warlich es sahe visierlich schön/

Als vorher giengen diese zween. ${ }^{21}$

The entertainment next presented a feat of mechanical engineering that reflected the duke's own fascination with innovative technologies. Four men, dressed as Indians in long, colourful, elaborate feather cloaks, feather headdresses, and decorated clubs, carried a green tree, a water well, and a cloud. Following de Bry's account of a water-tree on the island of Hierro, the well was presented as a gift that America had found on a Caribbean island. The mechanism showed how rain fell from the cloud into the well, from where a man pumped the water up to the tree for it to drip down again. This was to illustrate how a wondrous natural tree generated drinking water. ${ }^{22}$ The scene also signalled that travel mediated the marvels of God's nature, which he had distributed across the world and which humans could imitate through inventive technologies.

Several of the court and government officials involved in the procession were dressed in skin-coloured leather costumes so as to appear naked. This further underlines the considerable expense of these costumes, which were typically

21 All translations into English are by Pamela Selwyn. Bujok, Neue Welten, 15 .

22 Ibid., 16. 


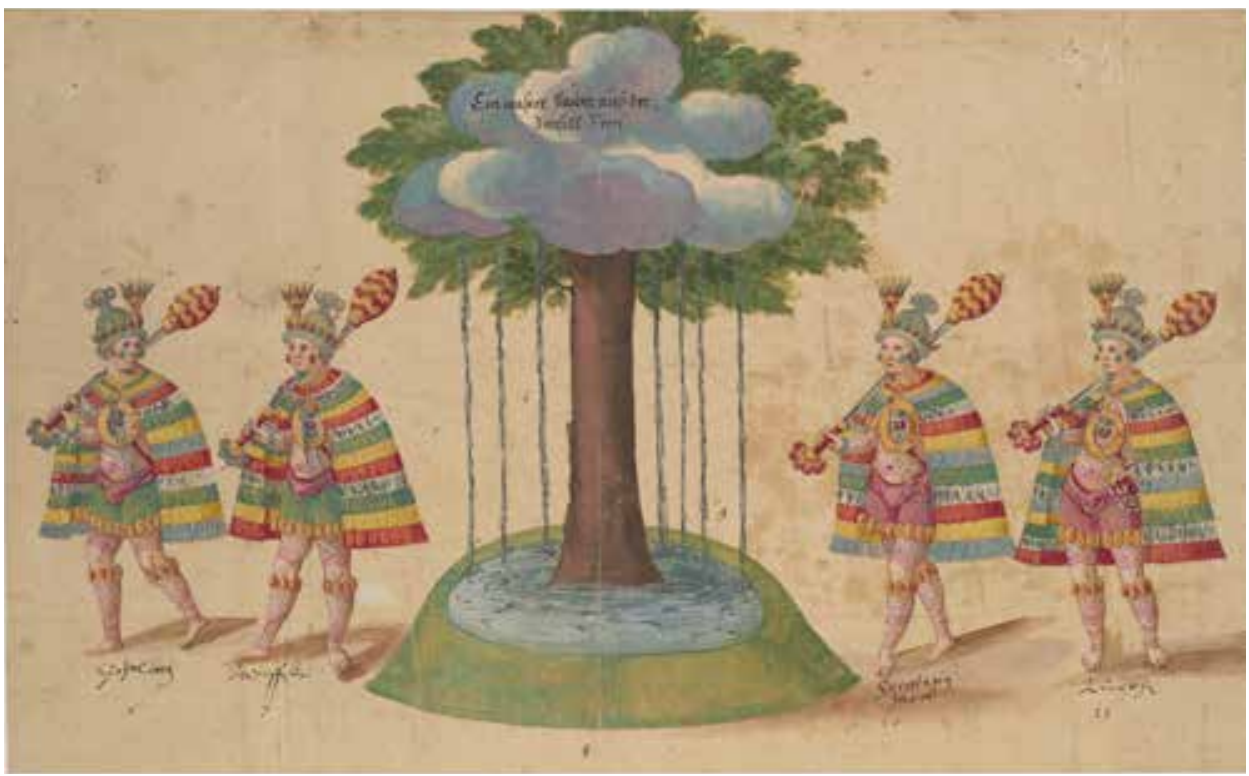

Figure 4.4: Procession at the Württemberg Court in Stuttgart, 1599: The second scene. Watercolour, pigment, and gold on paper, $30.5 \times 49.8 \mathrm{~cm}$. Weimar, Graphische Sammlungen, Klassik Stiftung Weimar, inv. no. KK 203. Image ๑ Stiftung Weimarer Klassik und Kunstsammlungen/Museen. Photo: Roland Dreßler.

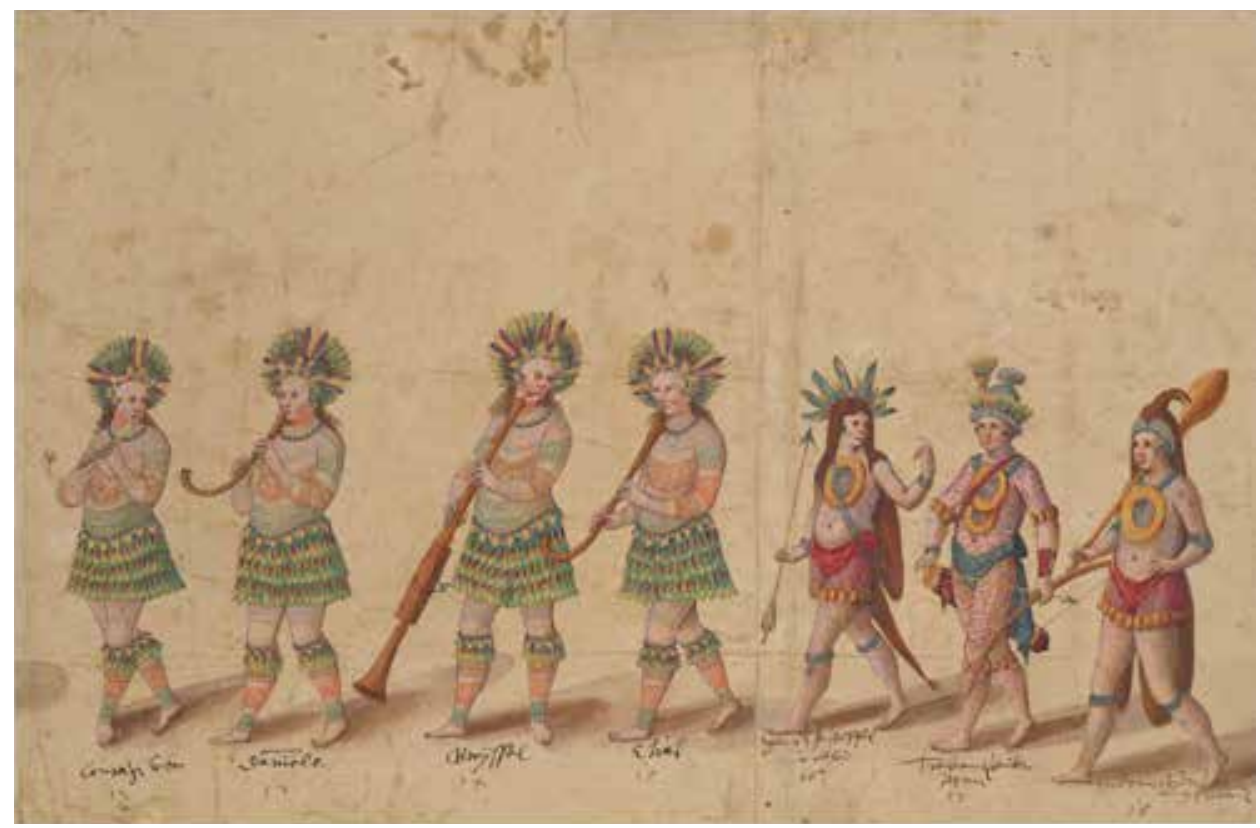

Figure 4.5: Procession at the Württemberg Court in Stuttgart, 1599: The third scene. Watercolour, pigment, and gold on paper, $29.9 \times 45.5 \mathrm{~cm}$. Weimar, Graphische Sammlungen, Klassik Stiftung Weimar, inv. no. KK 204. Image ๑ Stiftung Weimarer Klassik und Kunstsammlungen/Museen. Photo: Roland Dreßler. 


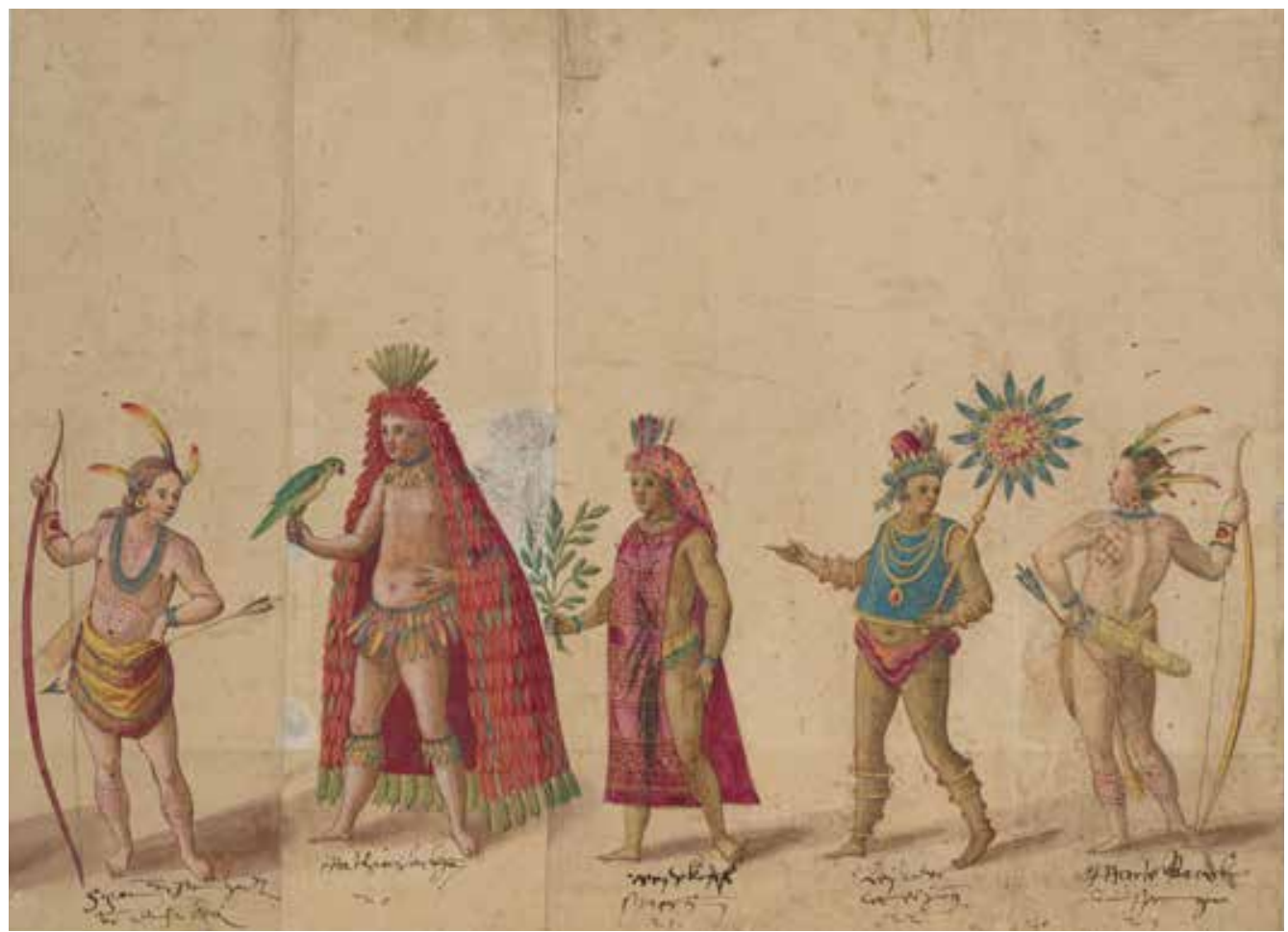

Figure 4.6: Procession at the Württemberg Court in Stuttgart, 1599: The fourth scene. Watercolour, pigment, and gold on paper, $29.8 \times 41.0 \mathrm{~cm}$. Weimar, Graphische Sammlungen, Klassik Stiftung Weimar, inv. no. KK 205. Image $\odot$ Stiftung Weimarer Klassik und Kunstsammlungen/Museen. Photo: Roland Dreßler.

created from cheap fabrics, such as flax or linen. ${ }^{23}$ The men were followed by a group of musicians, representing European traditions, and three guards dressed in feathers.

The following sequence of the procession involved twelve men elaborately dressed as Indians, several of them high-ranking noblemen to orchestrate the arrival of America. One of them held a real parrot and was clad in a spectacular foot-length, red feather cloak. This is likely to have been identical with one of two "cloaks of red and various other colours, parrot feathers, plus one attached hood" mentioned in a 1634 register of Indian dress used for courtly entertainments. ${ }^{24}$

Four men dressed as women, with baskets representing the riches of America through money as well as exotic fruit such as figs, melons, and lemons, ended this part of the procession. ${ }^{25}$

23 On nude costumes in masques see Schnitzer, Höfische Maskeraden, 64, 327.

24 As argued by Bujok, Neue Welten, 160.

25 Two final scenes showed a nobleman carried in a hammock and four women with horses, ibid., $19 f$. 


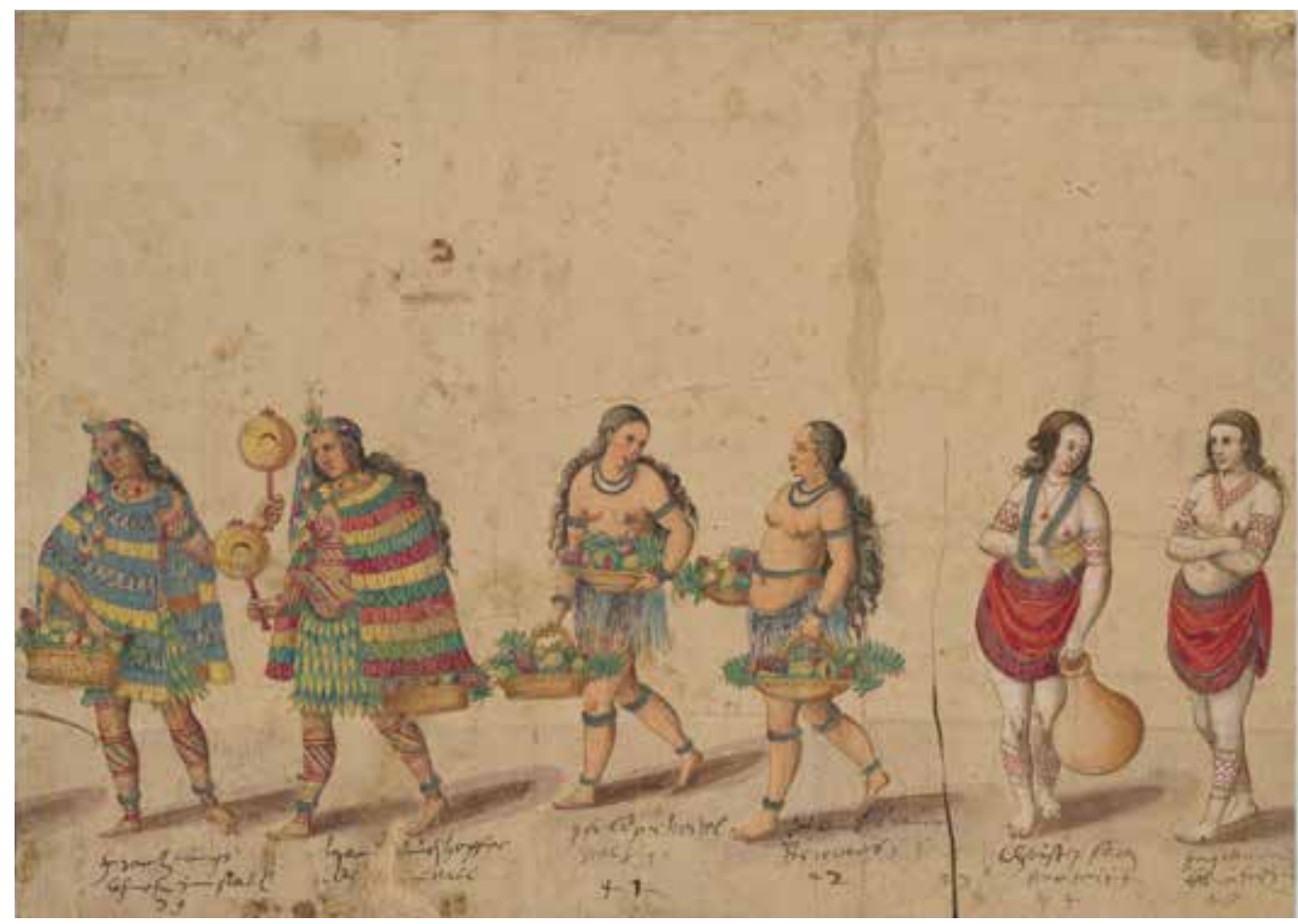

Figure 4.7: Procession at the Württemberg Court in Stuttgart, 1599: The seventh scene. Watercolour, pigment, and gold on paper, $29.8 \times 42.0 \mathrm{~cm}$. Weimar, Graphische Sammlungen, Klassik Stiftung Weimar, inv. no. KK 208. Image ๑ Stiftung Weimarer Klassik und Kunstsammlungen/Museen. Photo: Roland Dreßler.

Julius Caesar and Alexander the Great represented ancient rulers keen to witness America's inexhaustible riches and chart how much Germany had changed. This emphasized that textual knowledge about the classical world could no longer remain the sole guiding line for advancing civilizations who found themselves in a new world. Exchange derived from observing these cultures' notable achievements with one's own eyes (augenscheinlich sehen und erfahren). This empiricist stance invested ethnographic objects, alongside indigenous animals, plants, and people, with significance for knowledge-making.

\section{The Value of Curiosity}

Curiosity tied such knowledge to virtue rather than vice - even in women. Frischlin set out that the procession had been conceived particularly to please the ladies at court: Duchess Sybilla and her praiseworthy ladies-in-waiting, an entourage which resided in a "women's chamber" and was collectively addressed as das 
Frauenzimmer. While tournaments regularly focused on male figures, the ladies would enjoy seeing America as courageous and chivalrous. The procession was thereby presented as emblematic of the exchange desirable between sister continents and the opportunity for mutual benefit. ${ }^{26}$ Duchess Sybilla and her entourage were themselves in turn associated with a particular esteem of novelty and curiosity, as well as with an effect of luminosity:

Thus does (America) aim to please/

Extraordinary before all the other/

Highly esteemed ladies of the chamber/

Eager for something new and rarel

Shimmering in her fine array/

As is seldom seen in these lands.

So möcht (America) auch gefalln/

Weil sie ungwöhnlich für andern alln/

Dem hochlöblichen Frauwenzimmer/

Welchs Fürstlich gzieret her thut schimmern/

Und gern was news und seltsams sicht/

Welchs selten in den Landen gschicht $/{ }^{27}$

Sybilla even owned a piece of jewellery with rubies "made in the Indian manner" - perhaps one described in the account book as depicting two parrots. ${ }^{28}$ Attributes such as shimmering, shining, and "gleaming" repeatedly emphasized the ladies' honour. ${ }^{29}$ Frischlin set out that this February day had been brilliantly sunny, and Duchess Sybilla herself "glistened beautifully like a crystal." ${ }^{\circ 0}$ This ideal of "luminescent splendour" was central to sacred art since the Middle Ages - as it was to the embodiment of secular power - and was constituted through accessories. ${ }^{31}$ Courtly dress tried to maximize the light-reflecting properties of its fabrics through the use of silver and gold thread, extremely expensive and difficult to manufacture, as

\footnotetext{
26 See also ibid., 149f.

27 Frischlin, Auffzug, 27, my emphasis.

28 Fleischhauer, Renaissance, 404; HStAS, A 256, vol. 82, 372v.

29 I owe this point to Regine Maritz's important reading of the role of gender at the Württemberg court and her chapter on court festivities. Regine Maritz, "Gender as a Resource of Power at the Early Modern Court of Württemberg, c. 1580-1630" (PhD diss., University of Cambridge, 2018), 90-125.

30 Frischlin, Auffzug, 38.

31 See Herbert L. Kessler's crucial book Seeing Medieval Art (Toronto: University of Toronto Press, 2011), here 175 and for a wider exploration of this theme, Ulinka Rublack, "Renaissance Dress, Cultures of Making, and the Period Eye," West 86th: A Journal of Decorative Arts, Design History, and Material Culture 23 (2016): $6-34$.
} 
well as through precious, semi-precious, and gilded glass stones. ${ }^{32}$ Great amounts of money were invested in bejewelled wreaths or belts worn by high-ranking women. Frischlin hence noted that the spears and spurs carried as Zier by male participants had been beautifully gilded with silver and gold, and thus drew further attention to the labour, skill, and cost that had been invested in the event. ${ }^{33}$ The images of the procession suggest that feathers were embellished with powdered gold to heighten their preciousness. A marginal note in Frischlin's texts summarized: $U t$ est natura hominis novitates avida - a reference to Pliny - and translated: Man hört und sicht gern alle tage etwas neuwes: "Everyone enjoys daily hearing and seeing novelties." ${ }^{34}$ His account was printed in Frankfurt-am-Main rather than at the more local Tübingen press, and thus aimed at a broader German literate audience.

\section{The New Cultural Politics of a Lutheran Court}

As this suggests, Frederick was an ambitious and innovative ruler. ${ }^{35} \mathrm{He}$ had previously ruled over Montbelliard, a small territory attached to Württemberg which lay close to France. Here, Frederick defended Lutheranism, offered Huguenots a refuge, and had made available funds for one of Europe's first botanical gardens. Frederick began to rule over the house of Württemberg in 1593. He spearheaded innovation in agri- and viticulture, systematically surveyed fuel and mining resources, developed his interests in alchemy, embarked on ambitious building programmes, installed printing presses, and invested in diplomatic relations with France.$^{36}$ Giovanni Botero's bestselling treatise On the Reason of State, recently published in 1589 , spoke directly to the duke's idea that political power was strengthened by an investment in local natural resources alongside the improvement of domestic manufacturing and trade. Growth hinged upon knowledge about local environments - mineral, plant, and fossil resources, water reserves and climate conditions, good or bad winds. Botero, therefore, had influentially united economics with environmental thinking to propose a new political science which considered human affect as key.

32 Carolin Oster, Die Farben höfischer Körper: Farbattributierung und höfische Identität in mittelhochdeutschen Artus- und Tristanromanen (Berlin: De Gruyter, 2012), 66.

33 Frischlin, Auffzug, 44 and 55 for feathers on horses and gilding.

34 Ibid., 27.

35 See also Ulinka Rublack, The Astronomer and the Witch:Johannes Kepler's Fight for His Mother (Oxford: Oxford University Press, 2015).

36 Nicole Bickhoff, “'Gott kann der Welschen pracht nicht leiden': Hof- und Festkultur unter Herzog Friedrich I. von Württemberg," in Hofkultur um 16oo: Die Hofmusik Herzog Friedrichs I. von Württemberg und ihr kulturelles Umfeld, ed. Joachim Kremer, Sönke Lorenz, and Peter Rückert (Sigmaringen: Thorbecke, 2010), 73 . 
Human curiosity for a variety of goods and spending on new consumables, even luxuries, was to be encouraged, if they were domestically produced. ${ }^{37}$

Frederick wished the duchy's economy to grow through improvements in infrastructure, fortifications, milling, water-supply, mining and metal production, wine, silk, and linen production, as well as the cultivation of new varieties of fruit trees, animal-breeding, and bee-keeping. ${ }^{38}$ The Old Pleasure House, next to the castle, became the site of an ambitious alchemical laboratory. Alchemy involved not only the quest to turn base metal into gold, but was linked to a whole set of beneficial activities of a practical chemical kind, such as the improvement of health through "universal medicine," making sugar, refining salts, and dye, leather, glass, and gunpowder manufacturing. ${ }^{39}$ Hence the accounts register continuous entries for a wealth of materials delivered to the alchemists, which attracted much attention from within the court and involved courtiers and collectors, such as Carl Egen, who took part in the entertainment as Vespucci. ${ }^{40}$ Heinrich Schickhardt, the gifted engineer and architect, was another central figure at the court who accompanied Frederick to Italy and made beautiful drawings of new inventions.

In addition to this ambitious domestic policy, Frederick was determined to turn Württemberg court into an international Protestant power to be reckoned with and relied upon. He put great effort into diplomatic relations with other nations, travelled to see an ageing Elizabeth I, and maintained excellent relations with France to balance the power of the Habsburgs and protect Württemberg from her Catholic neighbour. ${ }^{41}$ Both countries honoured him with high decorations - England awarded him the Order of the Garter and France the Order of St Michael. An integral part of Frederick's international ambitions was the commemoration of his travels, entertainments, and achievements in print. Erhart Cellius, the Tübingen professor of poetry, oratory, and history, stressed the extraordinary medical benefits of alchemical discoveries made under Frederick's patronage as a magnificent art to facilitate a more enjoyable life. ${ }^{42}$

37 It is likely that Frederick would have encountered Botero's ideas through his travels in Italy before they were published in Latin from German printing presses in 1602. For a discussion of his ideas as related to a consideration of affects see Vera Keller, Knowledge and the Public Interest, 1575-1725 (Cambridge: Cambridge University Press, 2015), 38-45.

38 Walter Grube, Der Stuttgarter Landtag 1457-1957: Von den Landständen zum demokratischen Parlament (Stuttgart: Ernst Klett, 1957), 263.

39 Nettesheim (1486-1535) was widely known for his De occulta philosophia, 1531-1533, see William R. Newman, "From Alchemy to 'Chymistry'," in The Cambridge History of Science, vol. 3, ed. Katharine Park and Lorraine Daston (Cambridge: Cambridge University Press, 2006), 502; Tara Nummedal, Alchemy and Authority in the Holy Roman Empire (Chicago, IL: Chicago University Press, 2008), esp. 115, 127.

40 Fleischhauer, Renaissance, 393, describes Egen as an alchemist.

41 On Paludanus's collection see Harold Cook, Matters of Exchange: Commerce, Medicine, and Science in the Dutch Golden Age (New Haven, CT: Yale University Press, 2007), 116-130.

42 Erhard Cellius, Wahrhaffte Beschreibung Zweyer Raisen (Tübingen: Cellische Truckerey, 1603). 
The endorsement of improvement and enjoyment signals an important development within Lutheranism, which has been neglected in much of the historiography so far. It endorsed a positive outlook based on an interest in natural philosophy, travel, innovation, and economic policies. This vision was a world apart from the characteristically fatalist writings of many pastors in the Lutheran orthodox tradition. ${ }^{43}$ Just like Frederick's, several Lutheran princely courts during the later decades of the sixteenth century were active in their broad support of learning for the benefit of society. The Württemberg court was becoming a leading power among these, an intellectual as much as experimental, practical, and ambitious space in which duchess Sibylla built up expertise in herbal medicine and Frederick invested in a significant healing spa. Such practical learning connected them to ideas of positive regeneration by taking the products of the earth - minerals, plants, water, and geo-thermal heat - to improve life on earth. The secrets of nature, and past and present civilizations across the globe could be unlocked to benefit the body politic.

\section{Performing Colour}

Connected to this was an interest in the beauty and transformation of colours, which also inspired the fascination with featherwork. Cellius commented on the new manufacture of advanced wool weaving in the city of Calw. This was one of Frederick's large-scale, state-sponsored economic enterprises and spearheaded cameralist projects linked to the idea of shared pleasures in artificial things profitably produced in a polity open to industry, invention, the mechanical arts, and trade:

They spin/ and weave/ and dye there too

More finely than most others do.

And their pigments in the main

They procure from France and Spain.

Black/ yellow/green/grey/ brown/red/ blue

43 Thomas Kaufmann, Konfession und Kultur: lutherischer Protestantismus in der zweiten Hälfte des Reformationsjahrhunderts (Tübingen: Mohr Siebeck, 2006), 420-423. On the following see also AnneCharlott Trepp, "Natural Order and Divine Salvation: Protestant Conceptions in Early Modern Germany (1550-1750)," in Natural Law and Laws of Nature in Early Modern Europe:Jurisprudence, Theology, Moral, and Natural Philosophy, ed. Lorraine Daston and Michael Stolleis (Aldershot: Ashgate, 2008), 129-131; Volker Leppin, Antichrist und Jüngster Tag:Das Profil apokalyptischer Flugschriftenpublizistik im deutschen Luthertum 1548-1618 (Gütersloh: Mohn, 1992). On the pluralism of Lutheranism in the seventeenth century see Thomas Kaufmann, Dreißigjähriger Krieg und Westfälischer Friede. Kirchengeschichtliche Studien zur lutherischen Konfessionskultur (Tübingen: Mohr Siebeck, 1998), esp. 149. 
And all admixtures of those hues/

The colours are varied to suit

And now enjoy a high repute.

Like Spanish pink and carmine/

Grass: Swiss: Dark: parrot green.

Gold: sulphur yellow/ fine violet/

And whatever else the plants beget.

With these wares you'll gain renown/

At Strasbourg/ Frankfurt or Nördlingen town.

They bring them there by wagon and cart/

And earn good profits from the start.

Man spint/ man webt/ man färbt alda

So schön als irgendts anderstwa.

Auß Frankreich und Hispanien

Haben sie ihre KunstFarben.

Als schwarz/gelb/grün/graw/ braun/blaw/ rhot/

Und was jedes für mischung hat/

Daß Farben werden mancherley/

Die jetzund seind im besten geschrey.

Wie Spannisch Leibfarb/ Carmesin/

Gras: Schweitzer: Dunckel: Sittichgrün.

Gold: Schwäbelgäl/ schön Violfarb/

Und wie es gibt durchaus die Garb.

Mit diesen Wahren könnens bstehn/

Zu Straßburg/ Frankfort/ Nördlingen.

Mit Wagen/ Karn führt mans dahin/

Und haben dessen guten Gwin. ${ }^{44}$

Just as travel was praised as mediating technological knowledge through the water-tree from Hierro in the 1599 entertainment, and America was presented as Europe's sister, so the emphasis here lay on the use of French and Spanish dyestuffs, which enabled fashionable innovation. Spannisch Carmesin referred to the deep, scarlet red that cochineal imported by the Spanish from Mexico made so much more accessible. Such global trade was seen to profitably enable new industry in Württemberg's Black Forest to compete at the Frankfurt fair, Strasbourg, and important Franconian fairs. Green was a particularly difficult dye to achieve through vegetables and minerals, which explains Cellius's emphasis on the sophistication 
of the four different kinds of green which the Calw weavers traded in as a response to consumer demand. Profit, therefore, did not have to be a product of selfishness.

Duchess Sibylla owned at least one costume book and Frischlin's 1602 description evoked the deep, vibrant, innovative, and varied colours of Sibyllia's entourage, which could be seen to match the colour of New World feathers:

The ladies of the chamber followed/

Three and twenty shimmering came/

In twos/ then threes/ they walked apace

Their neck-ruffs finely edged with lace

And glistened in every lovely hue/

Their sleeves now snow white and then blue/

Now a grey that was so light/

Now a green/ or red so bright/

Others gleamed in violet tones/

In silvered garb the many went/

To gaze upon this tournament.

Darauff so folgt das Frawenzimmer/

Drey und zwanzig Glieder schimmern/

Giengen allwege zwo/ dann drey/

Ihr Kröser waren schön gespitzt/

Und haben hübsch von Farben glitzt/

Die Ermel waren etwan blaw/

Zum theil schneeweiß/ und dann liechtgraw/

Zum Theil auch grün/ dann etwa rot/

Manche von feyolfarb da gaht/

In silbern Stücken giengen vil/

$\mathrm{Zu}$ sehen dieses Ritterspiel. ${ }^{45}$

The women performed, in other words, particular dye-tones such as violet (feyolfarb), which could now be achieved locally. ${ }^{46}$ This rendered consumption virtuous "personal desires," as Vera Keller shows, could "be harnessed to serve public ends."47

Protestant rulers around 1600 such as Frederick of Württemberg or Moritz of Hesse were thus "prince-practitioners" - open to progressive learning through

45 Frischlin, Auffzug, 39 .

46 Fleischhauer confirms that court dress in Frederick's reign was more vibrant in colour than under his son John Frederick, Renaissance, 338.

47 Keller, Knowledge and the Public Interest, 14. 
practice, discovery, and esteem of the arts and crafts in order to spearhead harmony and progress in their realms. ${ }^{48}$ Frederick even entertained intimate relations with craftswomen - he cultivated affairs with a female house-tailor and a specialized washerwoman, for example. ${ }^{49}$

\section{The Element of Air}

Cellius stressed that God provided everything humans needed on earth, and that Frederick knew how to take hold of these possibilities and thus comprehend the world with his hands (Also begreifet Er die Erd Mit Seiner Hand). This was linked to deep comprehension of the four elements..$^{5}$ Cellius in turn celebrated Frederick as a master of these elements - earth, water, fire, and air. The earth provided plants, minerals, nourishment, and splendid dress, if rightly cultivated, and Frederick had even begun to produce silk locally. He had widened navigation, developed healing spas, and ensured that wells provided clean water. The element of fire was cultivated through managing the duchy's supply of wood and alchemical projects.

Air and winds were another essential element. Fredrick had ensured that the air in the duchy was fresh and well-becoming. Its mountainous regions brought refreshing winds for those who lived in valleys. The territory thus benefited from the right natural climate. This meant that people were enlivened by the air:

'Tis not lazy/ not sluggish/ not dense/ not heavy/

But blows instead towards the mountains.

Banishing foul vapours and damp

Which otherwise harm man and beast.

The air beneath and on the earth/

Therefore serves the common good:

So all the fruits may be their best/

And all that lives may benefit:

Most specially the feathered beasts

For whom the air is all and all.

'Tis why so many game birds gather/

Surpassing the numbers in other lands.

\footnotetext{
48 Bruce T. Moran, The Alchemical World of the German Court: Occult Philosophy and Chemical Medicine in the Circle of Moritz of Hessen (1572-1632) (Stuttgart: Steiner, 1991), 8, 11-12; see also Rublack, The Astronomer. 49 Paul Sauer, Herzog Friedrich I. von Württemberg 1557-1608: Ungestümer Reformer und weltgewandter Autokrat (Munich: Deutsche Verlags-Anstalt, 2003), 171-174.

5o Cellius, Zweyer Raisen, 3 o.
} 
Nicht faul/ nicht träg/ nicht dick/ nicht schwer/

Sondern geht auff den Bergen her.

Vertreibt bös Dämpff und Feuchtigkeit

Die Menschen und vieh sonst thun Leid.

Der Lufft unter und auff der Erd/

Mit grossem Nutz dahero fehrt:

All früchten desto besser sein/

Und was drin lebet in gemein:

Sonderlich aber Feder Thier

So den Lufft brauchen für und für.

Drumbs auch vil Feder Wildprett hat/

Und vilen Landen weit fürgaht.

Cellius now pointed out that he had himself heard others comment that there was no other country like Württemberg..$^{1}$

This respect for Frederick's environmental politics and the duchy's climate provides an important clue to understand the period's new esteem of feathers as well as birds. As Sandra Cavallo has shown, Italian medical writers increasingly presented air as a "palpable presence," which was defined by its "density and texture as well as by its colour and smell." ${ }^{2}$ This notion is equally reflected in Cellius's notion of "lazy," "heavy" air as harmful and the benefit of good air to dispel humidity and bad vapours. Good air remained invisible, but affected the body and soul, while winds, since antiquity, had been thought of as a "vivid presence." At their best, they stimulated "inner vitality." 53

Feathers in turn would have functioned like a sensor to register the quality of air. Bad air would make them stick and droop through humidity and stagnation, characterized through heaviness and density which at worst upset the mind. Good air possessed its own texture which responded to the fragility of feathers. It was "light, thin, transparent and fresh" as well as mobile. This helped to create cheerfulness and literally a lighter spirit. ${ }^{54}$

Cellius's poem underlines that humidity, in particular, was regarded as a major health hazard for man and animals. An abundance of birds, in turn, with healthy,

51 He ended by once more lauding Frederick as a man who had travelled to see other countries and was known to further develop the advantages of his own, ibid., 35 .

$5^{2}$ Sandra Cavallo, "Health, Air and Material Culture in the Early Modern Italian Domestic Environment," Social History of Medicine 29, no. 4 (2016): 695-716.

53 On the influential Greek discourse see the fascinating chapter on winds in Shigehisa Kuriyama, The Expressiveness of the Body and the Divergence of Greek and Chinese Medicine (New York: Zone Books, 1999), $235,246$.

54 Cavallo, "Health, Air and Material Culture," 704f.; and Sandra Cavallo and Tessa Storey, Healthy Living in Late Renaissance Italy (Oxford: Oxford University Press, 2013). 
glistening, fluttering feathers thus instantiated Württemberg's wise environmental policies and ideal climate for the spiritual and physical benefit of mankind. In addition, birds traversed cultures and were esteemed for the beauty of their colours and iridescent effects. In the alchemical tradition, feathers, moreover, indicated transformation into air and a different spiritual state. An interest in American featherwork, exotic as much as indigenous birds and feather-making, could thus become part of a wider world view and vision of political order. This newly intensified encounter with feathers and birds became an active part of how Europeans could construct symbolic systems with social as much as emotional meanings.

\section{Acquiring a Cabinet}

Frederick's collecting for a cabinet of curiosities was therefore integral to this new cultural politics at the Württemberg court. Johann Jakob Guth von SulzDurchausen (1543-1616) was his appointed chamber-master, a notable collector of curiosities and present at the 1599 procession. Frischlin lauded his intelligence and learning. ${ }^{55}$ In the year before Frederick's death, Sulz's collection - valued 20,00o Imperial florin - was visited by the Augsburg art agent Philip Hainhofer, and contained an unusually large number of 916 ethnographic objects, including clothing, featherwork, and adornments from India. ${ }^{6}$ Guth von Sulz gained prestige by adding to the significance of the Württemberg court and acted as a cultural broker who acquired considerable knowledge about many of his ethnographic novelties, which showed how grass, fibre, teeth, bones, wood, stones, shells, metals, and feathers were used in ingenious ways. His collection included 250 adornments from Virginia and Florida no less, which were depicted in de Bry's work. ${ }^{57}$ Guth thus cultivated an interest in national styles of craftsmanship that an international court could showcase as "intellectual capital" to record and stimulate technical developments. ${ }^{5}$ In addition, Carl Egen, the courtier impersonating Vespucci who was interested in alchemy, repeatedly bought rare and exotic goods at very high prices for the duke at the Frankfurt fair and elsewhere. ${ }^{99}$ The two Aztec shields are very likely to have been in the possession of Niclas Ochssenbach (1562-1626), whom

55 Frischlin, Auffzug, 40. On Guth von Sulz see Werner Fleischhauer, Die Geschichte der Kunstkammer der Herzöge von Württemberg in Stuttgart (Stuttgart: Kohlhammer, 1976).

56 Bujok, Neue Welten, 125; HStAS, A 20a, vol. 4.

57 Bujok, Neue Welten, 127 f.

$5^{8}$ The term is Mark Meadow's, see his "Merchants and Marvels: Hans Jakob Fugger and the Origins of the Wunderkammer," in Merchants \& Marvels: Commerce, Science and Art in Early Modern Europe, ed. Pamela H. Smith and Paula Findlen (New York: Routledge, 2002), 193.

59 See, for instance, HStAS, A 256, vol. 97, 362r. 
Frederick had favoured with a position as captain of Tübingen's castle, and who in turn also received objects from Egen. ${ }^{60}$ Frederick showed his own acquisitions to high-ranking Protestant rulers when they visited. In 1602, for instance, Moritz of Hesse noted "beautiful Indian costume made from feathers." ${ }^{61}$

Did Frederick, as much of the literature suggests, acquire many of these artefacts from Bernhardus Paludanus, the Dutch humanist? ${ }^{62}$ Jacob Rathgeb, the ducal secretary, described Frederick's visit of Paludanus's collection when he travelled from Montbelliard and provided an overview of it as a separate booklet of twentyfour pages, which was bound into the account of Frederick's travels. ${ }^{63}$ The visit underlines Frederick's keen interest in natural knowledge, artefacts, and encounter. Amsterdam around 1600 quickly became a hub of global trade in exotica and natural materials, among them birds, featherwork, and clothing. ${ }^{64}$ Alongside England, the Dutch Republic was now a global Protestant power. Frederick made every effort to visit Paludanus on his return from England in 1592, travelling to the Dutch port town of Enkhuizen, seven miles by sea from Amsterdam. ${ }^{65}$

The duke encountered a forty-two-year-old man who had studied medicine in Padua and afterward travelled through Europe, Asia, and Africa. Upon his return to the Dutch Republic, Paludanus had first taken up a position as town physician in Zwolle and then, in 1586, in the port town of Enkhuizen. He collected artefacts and naturalia. Since 1575 , he also kept an unusually extensive album amicorum that included not only the signatures and coats of arms of his many guests, but also about 145 costume figures from different lands (Fig. 4.8). ${ }^{66}$ Paludanus at the time of Frederick's visit, moreover, closely collaborated with Jan Huygen Linschoten (b. 1562), a native of Enkhuizen, and would help him to prepare his pioneering, richly illustrated

\footnotetext{
6 o Bujok, Neue Welten, 112-114.

61 Ibid., 109 .

62 The abundance of featherworks used for the 1599 entertainment might have been lent from the Kassel court, which had recently staged a small procession of America, as well as from the collection of the Tübingen castle-Hauptmann Niclas Ochssenbach. On the Kassel procession see Hartmut Brozinski and Günther Schweikhart, eds., Wilhelm Dilich: Ritterspiele anno 1596 (Kassel: Wenderoth, 1986). On Paludanus see F. W. T. Hunger, "Bernardus Paludanus (Barent ten Broeke) 1550-1633: Zijn verzamelingen en zijn werk," in Itinerario: voyage ofte schipvaert van Jan Huygen van Linschoten naer Oost ofte Portugels Indien 1579-1592, ed. C. P. Burger and F. Hunger, vol. 3 ('s-Gravenhage: Martinus Nijhoff, 1934), 249-268; Roelof van Gelder, "Paradisvogels in Enkhuizen: De relatie tussen Van Linschoten en Bernardus Paludanus," in Souffrir pour parvenir: De wereldd van Jan Huygen van Linschoten, ed. Roelof van Gelder (Haarlem: Uitg. Arcadia, 1998), 30-50.

63 Jacob Rathgeb, Kurtze und Warhaffte Beschreibung der Badenfahrt [...] (Tübingen: Cellius, 1602).

64 Claudia Swan, "Exotica on the Move: Birds of Paradise in Early Modern Holland," Art History 38 , no. 4 (2015): 621-635.

65 The distance is noted in the report by Cellius, Zweyer Raisen, 42.

66 This is held at the National Library of the Netherlands. Marika Keblusek is currently working on Paludanus's album. Frederick's own album amicorum did not contain costume figures.
} 


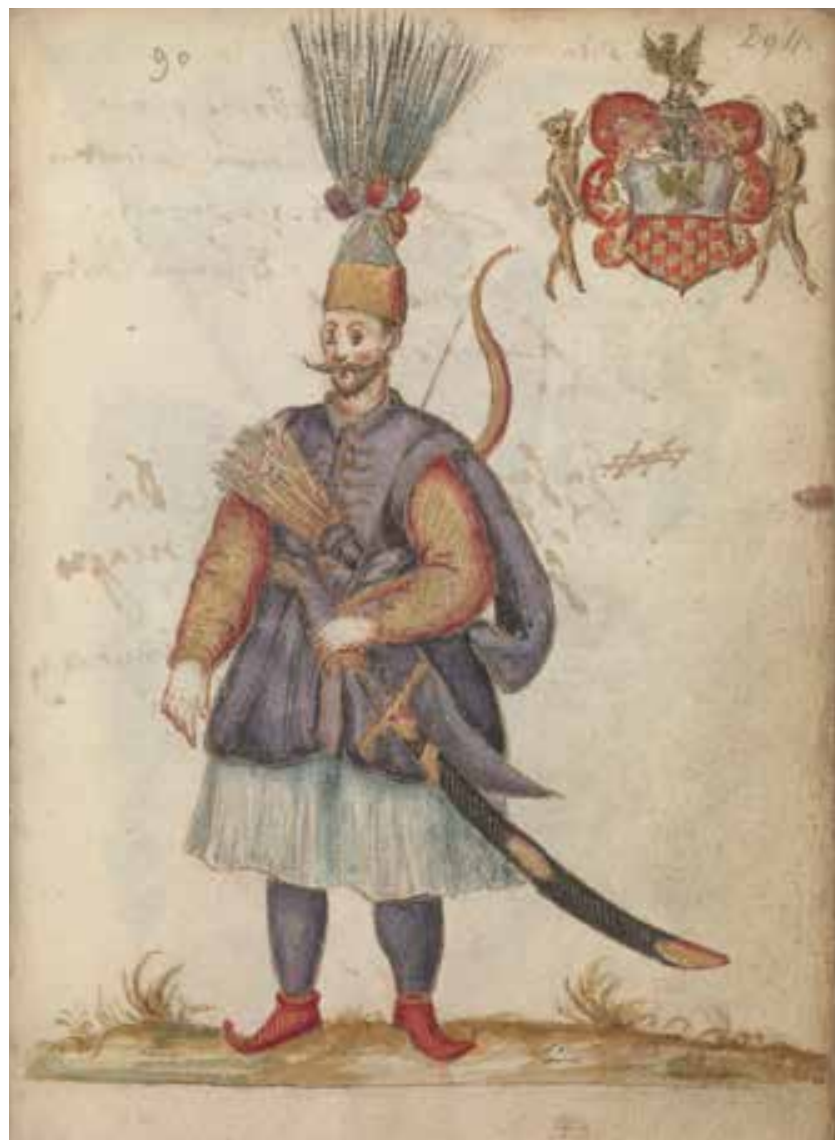

Figure 4.8: Costume image of an Ottoman soldier with a striking feather-headdress. Gouache and brown ink on paper, $15.5 \times 11.5 \mathrm{~cm}$. In album amicorum of Bernardus Paludanus, 1575-1630, fol. 294r. The Hague, Koninklijke Bibliotheek, shelf no. 133 M 63. Image @ KB | National library.

description of his voyage to Goa and Asian countries with which the Portuguese traded. Linschoten's Itinerario was published in 1595-96 and quickly translated into Latin, English, and French. It stood out for its carefully observed costumes of Portuguese men and women as well as Asians ranging from China to India. ${ }^{67}$

The town of Enkhuizen that Frederick set foot on thus was a microcosm of global knowledge-making in which the claim to first-hand experience through travelling was evidenced through costume, images of costumes, and artefacts as much as writing. This yielded men authority and commodities with which to profitably trade. Linschoten - who was hailed as a "Dutch Magellan" - had brought back his

67 Ernst van den Boogart, Civil and Corrupt Asia: Image and Text in the Itinerario and the Icones ofJan Huygens van Linschoten (Chicago, IL: Chicago University Press, 2003). 
own collection of manuscripts, books, naturalia such as birds of paradise, and artefacts. The former Enkhuizen town physician François Maelsen, as well as the local cartographer Lucas Jansz Waghenaer, belonged to the same Enkhuizen circle of those furnishing knowledge about cultures, which spurred on booming Dutch trade ventures and knowledge-making. ${ }^{68}$

For Frederick, this encounter would have strengthened confidence in an exciting Protestant future. Paludanus had visited Stuttgart in 1581, but it is unlikely that he had then met Frederick, who took over rule in $1593 .{ }^{69}$ Yet the Dutchman's travels through the German lands provided him with useful knowledge about a range of courts and collectors, which helped to demonstrate the advantages of his own collection of coins and minerals, such as different types of sand and stones, as well as plants and animal parts, costume, and handcrafted objects. The lengthy Latin table in Rathgeb's 1602 description of the duke's travels systematically set out the contents of the first ten cases of Paludanus's collection, and this was followed by a summary account of the complete collection in the vernacular as part of the body of the travel account. The collection amounted to 1,440 cases (Kästlin) in eighty-seven drawers (Laden). It was astonishingly comprehensive in naturalia. Six cases alone were filled with 253 types of coral. Rathgeb set out that, as this was "truly a cabinet of wonder," with objects from India and Egypt "and other far away countries which were at hand" and could not easily be brought together again, each piece was thus being described..$^{70}$ Case 63 contained twenty drawers and "foreign birds, including three birds of paradise/ and the clothes made from Brazilian feathers." Case 87, the final case, contained "all sorts of clothes and foreign things from Syria/ Persia/ Armenia/ East and West India/ Turkey/ Arabia/ Muscovy/ etc. in many hundreds." Rathgeb enigmatically ended his account at this point by noting: "all of which I shall put into a case when there is time to do so and send to his highness Duke Frederick."71

This passage in the main body of the text has usually been interpreted to indicate that Frederick bought Paludanus's entire collection. More recently, however, Sabine Hesse has argued that this is unlikely, as the Latin inventory itself notes four gifts from Frederick, such as terra sigillata. She argues that the exotica in case 87 were not

68 Ibid., 4-5.

69 Paludanus's entry in Frederick's album amicorum likewise dates from 1602 and supports that the men only met in 1602, see Ingeborg Krekler, Die Handschriften der Württembergischen Landesbibliothek Stuttgart, vol. 3: Stammbücher bis 1625 (Wiesbaden: Harrassowitz, 1999), StB, Nr.9. On Paludanus's career see Cook, Matters of Exchange, 115f., which provides a detailed account of Paludanus's travels in Europe. 70 Rathgeb, Badenfahrt, 132.

71 Cellius, Zweyer Raisen, 156: "Noch eine Laden darinn allerley Kleydungen und fremde sachen/ auß Syria/ persien/Armenien/ Ost und West Indien/ Türkheyen/ Arabien/ Muscovien/ etc zu ettlichen hunderten/ die ich alle mit gelegenheit und zeit/ ein jeglichs in sein kasten stellen soll/ und E.F.Gn. zustellen." 
destined to be sent to Frederick as artefacts but were meant to be incorporated into the systematic order of Paludanus's own collection. She correctly notes, moreover, that Paludanus's inventory was sent to Frederick after the trip had been completed, and in fact after Frederick had risen from ruling over Montbelliard to ruling over Württemberg, as the inscriptions of his gifts indicate..$^{2}$

Yet a third possibility appears to be that not the entire collection, but only the final case with "various clothing and strange things" in their hundreds, was sent to Stuttgart. It was discussed without reference to a number, was not part of the Latin inventory, and was subsequently referred to in German at the very end of Rathgeb's account of the visit. Rathgeb's enigmatic note might well indicate that only this part of Paludanus's collection was transferred to Stuttgart. ${ }^{73}$ As Rathgeb refers to this task, there remains little doubt that either the whole collection or this section was bought by the duke, but Hesse is right to point out that the fact that the Latin inventory shows that ducal gifts had later been incorporated indicates that the main body of the collection is likely to have remained in Enkhuizen. It would have been a strange decision for Paludanus in 1592 to sell off his entire collection, especially since these were the crucial years of his collaboration with Linschoten. On the other hand, when a duke of Pomerania visited Stuttgart in 1602, his tutor noted that Frederick's cabinet "had not so many marvels as foreign rarities, most of which the current duke has bought for a lot of money from doctor Paludanus and among which the most noble pieces cost him around six thousand Thaler." Hence the evidence is far from clear. ${ }^{74}$

The implication of the possibility that only the unnumbered final case was transferred is twofold. It underlines Frederick's early and distinct interest in possessing authentic foreign dress, including featherwork, which he could then use in entertainments. The inclusion of Paludanus's inventory, moreover, might explain the success of Rathgeb's 1602 publication, prepared in at least five editions, and even more so its success as part of Cellius's 1603 and 1604 editions of Rathgeb's account alongside an account of Frederick's voyage to Italy in 1599, which took place after the Stuttgart entertainment. At least twelve editions of these travel accounts and Cellius's celebratory poem survive. The inventory of Paludanus's collection in Latin would have been of interest to an international audience of art lovers and natural philosophers, and the record of Frederick's gifts for Paludanus's collection prominently positioned him among them.

By 1625, Jakob Bornitz's (1560-1625) treatise On a Sufficiency of Things laid the ground for a political analysis of the role of art and crafts. Its list of notable European

72 Hesse, "Neue Welt in Stuttgart," 146, fn. 16.

73 Rathgeb, Badenfahrt, 156, as above. Paul Sauer also seems to have adopted this interpretation of the text, see his Herzog Friedrich, 145.

74 For Gerschow's report and the unresolved assessments of whether the Paludanus collection formed a major part of Frederick's cabinet see Die Kunstkammer der Herzöge von Württemberg, 104-105, 73-75. 
collections was painstakingly copied down by the pan-European Protestant reformer Samuel Hartlib (160o-1662). This underlines the enduring effect of Frederick's collecting strategy, which linked him to Paludanus, whom Bornitz had likewise himself visited. Major collections, Bornitz noted, were to be found in or at:

The courts of the elector of Saxony

The Landgrave of Hesse

The Grand Duke of Tuscany

The Duke of Württemburg in Stuttgart

The Duke of Bavaria in Münich

and in the home of the doctor Paludanus in Enkhuizen. ${ }^{75}$

As Vera Keller has shown, Bornitz was a leading Lusatian jurist with close connections to Rudolf II's court in Prague. He was engaged in debates about universal reform alongside prominent Württemberg writers such as Christoph Besold and Johann Valentin Andreae. Bornitz provided an early economic theory of how cameralism and artisanal knowledge benefited a body politic spearheaded by intellectually as much as physically engaged rulers. Such engagement manifested itself through travel and hands-on work as well as the way in which he animated a body politic through vital spirits. ${ }^{6}$

Bornitz thus came to theorize the practice of courts, such as in Württemberg under Frederick's rule, and likewise drew on the popular genre of art and recipe books, which described how to achieve dyes, make medicines, or style hair. ${ }^{77} \mathrm{He}$ celebrated humankind's potential for constant innovation and change, the desire for the inexhaustible new, the discovery of new techniques, as well as the recovery of ancient practical knowledge. The jurist endorsed the importance of alchemy and eventually listed an enormous number of things which ought to be seen as the foundation of civil and civilized societies rather than being decried as lamentable luxuries. He lauded Rudolf II's court in Prague for attracting so many foreign craftsmen who perfected nature through art. ${ }^{78}$ The many things Bornitz listed to show "everything art, nature, or learning could furnish" included confectionary or soap-balls, flowers, ribbons, and wreaths, and appeared alongside feathers and

75 Keller, Knowledge and the Public Interest, 172, my emphasis. On Bornitz see also Winfried Schulze's influential article, "Vom Gemeinnutz zum Eigennutz: Über den Normenwandel in der ständischen Gesellschaft der Frühen Neuzeit," Historische Zeitschrift 243 (1986): 591-626.

76 Keller, Knowledge and the Public Interest, offers a pioneering discussion of Bornitz's importance, 95-126.

77 He prominently draws on Balthasar Schnurr's enormous compendium, which kept on being republished throughout the seventeenth century.

78 Keller, Knowledge and the Public Interest, 116-118. 


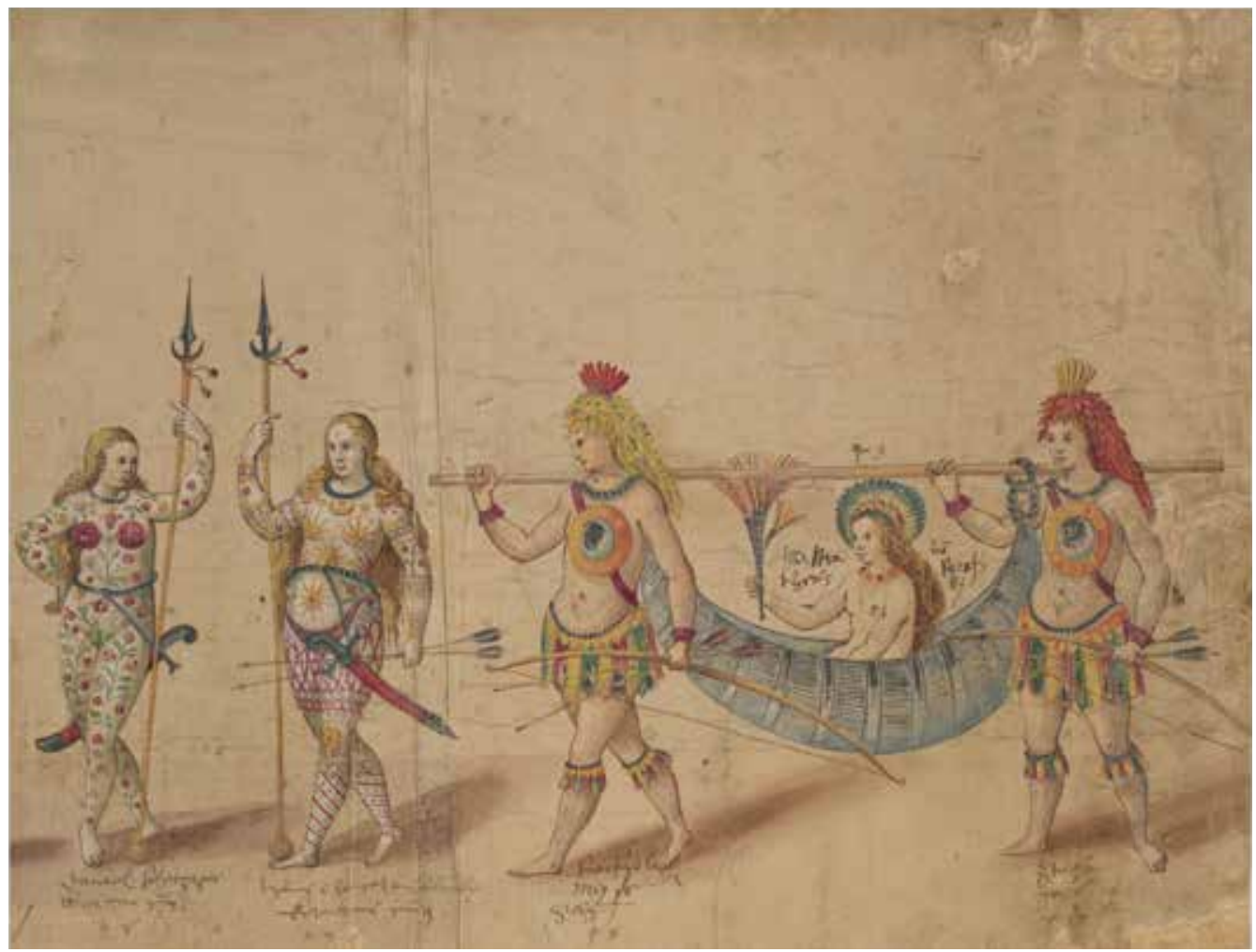

Figure 4.9: Procession at the Württemberg Court in Stuttgart, 1599: The final scene. Watercolour, pigment, and gold on paper, $29.6 \times 38.6 \mathrm{~cm}$. Weimar, Graphische Sammlungen, Klassik Stiftung Weimar, inv. no. KK 209. Image @ Stiftung Weimarer Klassik und Kunstsammlungen/Museen. Photo: Roland Dreßler.

their expert craftsmen, the Federschmucker ${ }^{79}$ Adapted from the Indies, these subtle, translational objects now served to embellish Europeans.

\section{Spending on Feathers}

This is borne out by the Stuttgart court's annual spending on featherwork, which is exceptionally well documented in the ducal treasury's account books. ${ }^{80}$ The court relied on several long-serving artisans of high quality who practised their

79 Jakob Bornitz, De Rerum Sufficientia in Rep.\& Civitate procuranda [...] (Frankfurt-am-Main:Tampachius and Weissius, 1625), ch. 89, 199, De plumariis.

80 Fleischhauer, Renaissance, 428 . The Landschreibereiakten provide a serial record that is preserved in its entirety - they contain c. 20 pages each year for spending on artisanal work, products, or materials, including spending on the alchemical laboratory. My thanks to Dr Stefan Hanß for transcribing the records for the reigns of Frederick and John Frederick - an edition will be published as Stefan Hanß, Court 
craft with their wives and passed on their knowledge to the next generation. In relation to silk embroidery and featherwork, this required the ability to work with particular ingenuity for festivities, tournaments, and masques. Frederick could draw on the extraordinary expertise of two longstanding colleagues entrusted with such work: the embroiderer Salomon Daubenhauer, who was also trained as an artist and was employed between $155^{6}$ and 1609-10; and the feather-worker Hans Dannenritter, employed between 1557 and 1602, who in addition to working with real or false feathers crafted from wool, also lined head-wear or provided hat-bands and multi-coloured silk ribbons. Daubenhauer and Dannenritter, in addition, jointly kept a shop. ${ }^{81}$ Further featherwork for the court was mostly supplied by one Adam Eßlinger, whose son continued alongside Ludwig Dannenritter after his father's death in 1602, and, between 1612 and 1634, Jakob Unangst. ${ }^{82}$

Expenditure on feathers and head-wear was considerable. In 1595, Hans Dannenritter, for instance, received a total of 921 florins for "feathers and work" carried out to suitably attire the Württemberg delegation for the Regensburg Imperial Diet. ${ }^{83}$ In 1596 , he received over 607 florins in connection with a tournament and masque, as well as a further 25 florins for featherwork supplied to the ladies at court and 4 florins for silk ribbons for those working in the ducal chancellery. ${ }^{84}$ These costs compare to those of a simple silver cup from a Stuttgart goldsmith for 14 florins in 1595-96, or the average price of 204 florins for a golden necklace from Augsburg during the same year. ${ }^{85} \mathrm{~A}$ bird of paradise sourced via Nuremberg cost 100 florins. ${ }^{86}$ In $1595-96$, a group of craftspeople were paid 809 florins specifically for work on entertainments. ${ }^{87}$ Even against this figure, the high cost of Dannenritter's contribution (6o7 florins) in $1596-97$ stands out. ${ }^{88}$

The account book roughly filled the same number of pages listing expenses year after year, which means that it is doubtful that every expense was noted. Moreover, while many of the entries precisely identified which objects had been paid for, others recorded in a summary manner that "Georg Gewandschneider from Nuremberg," a tailor, had been paid 770 florins, or a Frankfurt jeweller 50 florins "for numerous

and Material Culture in Early Modern Germany: A Sourcebook on the Duke of Württemberg's Payments to Artisans, Stuttgart, 1592-1628 (Amsterdam: Amsterdam University Press, forthcoming).

81 Fleischhauer, Renaissance, $234 \mathrm{f}$.

82 Ibid., 428.

83 HStAS, A 256, vol. 81, 332v-333v.

84 HStAS, A 256 , vol. 83,365 r.

85 HStAS, A 256, vol. 82, 370v.

86 HStAS, A 256, vol. 83, 356r.

87 HStAS, A 256, vol. 82, 378rf.

88 HStAS, A 256, vol. 83,365 r. 
things," while Carl Egen purchased goods worth 674 florins at the Frankfurt fair in $1596-97$, some of which might well have been exotica. ${ }^{89}$

The account books, therefore, cannot serve as a basis for any exact statistical analysis. Yet they clearly suggest that feathers and indigenous featherwork for the entertainment in February 1599 were accumulated and perhaps already used in previous years and relied on a network of intellectuals, dealers, and craftsmen in Nuremberg and Augsburg. Most interestingly, Levinus Hulsius of Nuremberg was paid 216 florins for "several Indian and other things." Hulsius was born in Ghent in 1546 and had sought refuge in Germany in 1583 . He is well known for his interest in mathematical and astronomical instruments, publishing Tycho Brahe, and also trading instruments, many of which promised to improve navigation and thus commercial success. In addition, Hulsius translated travel accounts from Dutch into German, notably an account of East Indian voyages in 1598. Like other travel accounts from his press, these cheap, illustrated quartos were so successful that they complemented de Bry's..$^{90}$ What has gone unnoticed so far is that, just as he dealt in instruments, Hulsius also traded Indian artefacts, which he most likely sourced via Amsterdam or the Frankfurt fair. The brokerage of such artefacts could be interlinked with a wider set of intellectual and economic engagements, rather than simply being a matter of supplying "costume."

Meanwhile, Zachariae Ringswanden, another Nuremberg dealer, received the considerable sum of 209 florins in 1598 just for parrot feathers. At the same time, decorated parrot feathers retailed for about 1 florin in Nuremberg. ${ }^{91}$ Ringswanden was soon asked to send additional parrot feathers for 39 florins, while a Ludwig Heinzeln was reimbursed another 200 florins which he had paid the same dealer..$^{22}$ Very soon after these payments, an Augsburg feather-worker named Augustein Weltz was paid 500 florins for the "masque for the Ringlinrennen," while a number of temporary painters who had been employed on a daily basis for the entertainment received a mere 25 florins. ${ }^{93}$ One parrot had been acquired for 40 florins. ${ }^{94}$ Perhaps because Weltz had been brought in from Augsburg, Hans Dannenritter received only 98 florins for featherwork carried out between July 1596 and February $1598 .{ }^{95}$

89 HStAS, A 256, vol. 82, 372r; vol. 83, 353r.

90 Michiel van Groesen, The Representation of the Overseas World in the De Bry Collection of Voyages (1590-1634) (Leiden and Boston, MA: Brill, 2008), 346-351.

91 Jutta Zander-Seidel, Textiler Hausrat: Kleidung und Haustextilien in Nürnberg von 1500-1650 (Munich: Deutscher Kunstverlag, 1990), 226.

92 HStAS, A 256, vol. 85, 376v-377r.

93 Ibid., $378 \mathrm{r}$.

94 Ibid., 372v-378r.

95 Ibid., 38 or. 


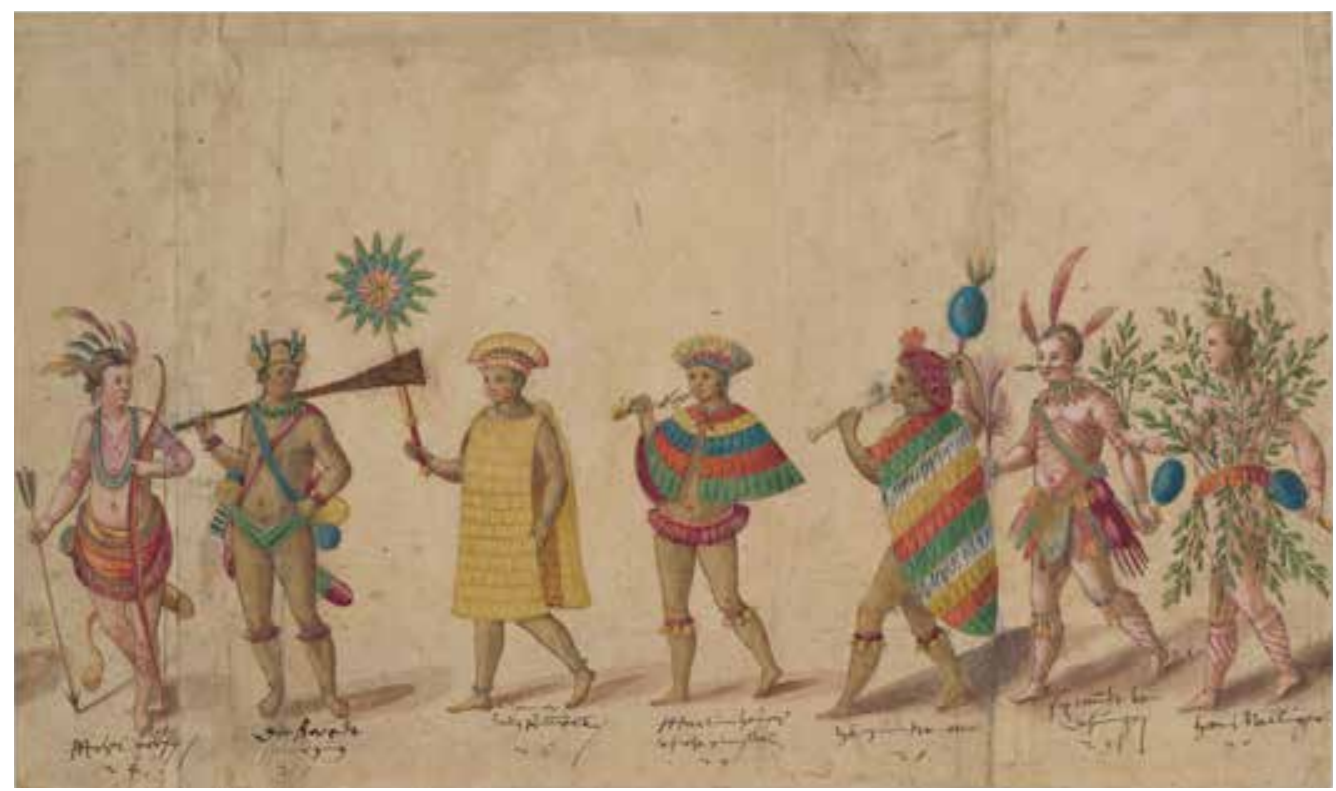

Figure 4.10: Procession at the Württemberg Court in Stuttgart, 1599: The fifth scene. Watercolour, pigment, and gold on paper, $30.0 \times 50.9 \mathrm{~cm}$. Weimar, Graphische Sammlungen, Klassik Stiftung Weimar, inv. no. KK 206. Image $\odot$ Stiftung Weimarer Klassik und Kunstsammlungen/Museen. Photo: Roland Dreßler.

Susanna Mentler from Augsburg, meanwhile, was paid 28 florins for making wigs for the entertainment with "curled human hair." ${ }^{96}$

The accounts for 1598-99 indicate that Dannenritter's expertise was reinstated: he was paid 400 florins for featherwork carried out between 28 March 1598 and 12 April 1599, the period which included the February show. ${ }^{97}$ Shortly after, he received 10 florins for five feather tips, while the painter who recorded the entertainment on parchment was paid 20 florins for the task..$^{8}$ During the following year, Carl Egen received 142 florins for "all sorts of Indian things" he had bought for Frederick, while Dannenritter received 132 florins - very much his average pay for routine work carried out at the court. ${ }^{99}$ Overall, Dannenritter was nonetheless paid 9,500 florins between 1557 and his death in 1602 - more than 200 florins on average per year just for his work for the duke, which indicates his respectable income. $^{100}$

The account books, in other words, provide evidence that despite the later reports, which emphasized the exotic nature of all feather-costumes used in the

96 Ibid., $384 \mathrm{v}$.

97 HStAS, A 256, vol. 86, 383 r.

98 Ibid., $383 \mathrm{v}, 384 \mathrm{r}$.

99 HStAS, A 256, vol. 87, 362r, 376v, see his salary of 116 florins in 16oo, HStAS, A 256, vol. 88, 379v.

100 On the overall figure see Fleischhauer, Renaissance, 235. 
entertainment, considerable sums of money had also been spent on the skilful German re-crafting of an Indian look. Paludanus's and other original artefacts would have served as models to imitate Indian fibre and textile arts and become more familiar with them. ${ }^{101}$

\section{The Politics of Feathers}

Frederick I of Württemberg unexpectedly died in 1608. His son Johann Friedrich took over rule just as the Protestant Union was founded as a military coalition in a new age of fragile Imperial governance and greater confessional tension. The official description of his marriage festivities with Barbara Sophia of Brandenburg in 1609 argued that Germans had acquired greater experience and ingenuity than other nations through their keen travelling. ${ }^{102}$ John Frederick inherited and added to the cabinet, which he showed off to the young Calvinist ruler Frederick $V$ of the Palatinate and his wife Elizabeth as well as Duke Frederick III of Schleswig-Holstein as important guests in $1616 .{ }^{103} \mathrm{He}$ had been thoroughly socialized into a world view which accorded indigenous featherwork and birds great significance, and in 1607, for instance, had taken back "lots of Indian things" for his father's cabinet when he returned from a trip to the Netherlands. ${ }^{104}$

The duchess and her courtly ladies now spent much more freely on luxuries and attire. Entertainments became ever more lavish. In 1616, the ducal couple celebrated the baptism of their son during one of the new Protestant Union's most formidable festivities. The entertainment focused on Germany's united interests against the threat of over-powerful Catholic Habsburg rule, and emphasized the importance of patriotism. ${ }^{105}$ The notion that Württemberg's virtue could inspire Germany and spread globally was retained, as was the notion of a dialogue with representatives of such nations.

Remarkably, Ferdinand Geizkofler, a leading court politician, appeared as "regent of Madagaskar" with an entourage dressed from top to toe in green- a colour

101 For a brief discussion of separate lists from 1634 that contain indigenous feather costumes for entertainments see Bujok, Neue Welten, 160 .

102 Alexander Schmidt, Vaterlandsliebe und Religionskonflikt: Politische Diskurse im Alten Reich (1555-1648) (Leiden and Boston, MA: Brill, 2007), 336, fn.420.

103 Bujok, Neue Welten, 104; Fleischhauer, Renaissance.

104 Hesse, "Neue Welt in Stuttgart," 143.

105 Schmidt, Vaterlandsliebe, 328-350; Laure Ognois, "Dass ein Cavallier seinen Dienst nicht besser kan anwenden, als denselben dem Vaterland zu nutzen den Unirten zu praesentieren: Politische Instrumentalisierung eines christlichen Ereignisses? Die Festtaufe Friedrich von Württembergs im Jahre 1616," in Union und Liga 16o8, 16og: Konfessionelle Bündnisse im Reich - Weichenstellung zum Religionskrieg, ed. Albrecht Ernst and Anton Schindling (Stuttgart: Kohlhammer, 2010), 227-262. 
associated with renewal, hope, and love. He announced that the people of America, Asia, and Africa all spoke about the virtue and perfection of the Württemberg court. A perfect knight, he declared, was "not only gotten by deeds of prowess," but also "by constancie and faithfulness in Love." This challenged the stereotype of African people as less civilized and more unruly in their desire. ${ }^{106}$

Above all, the masque sought to end dissonance in Germany and achieve concord among "great lords who by their wisedome shall reforme and confirm the old confidence of Germans." ${ }^{107}$ Virtue, and the stimulation of affects in accordance with a fortuitous constellation of Sagittarius over Stuttgart, was expected to increase the population's love of the German fatherland and freedom. ${ }^{108}$

Feathers, dress, and translucent jewellery now formed an assemblage of accessories that structured perceptions and affects. The lengthy festival description in German and English noted a variety of feathers used and their colours as well as their effects. The Augsburg art agent Hainhofer particularly lauded the joyful, friendly manner of the princess, who spoke many languages, but preferred fluent English and French, wore liberating English dress, danced gracefully, and galloped more energetically than her husband to hunt down five wolves, eighteen rabbits, a fox, and three herons. ${ }^{109}$ "The princess," he noted,

is stacked up with big diamonds, in her hair, on her sleeves, around her neck, on her ears, and especially she wore a diamond collar on her bare chest, (as the ladies now sport the English manner, wide and open at the front), with beautiful large stones (Clainot) which one estimates are worth a kingdom, and the image of this I send to the duke, and in her hair she wore small white feathers. ${ }^{110}$

Before sitting down for lunch, the princes put their hats aside and this gave Hainhofer the opportunity to inspect them alongside a court councillor, who acted as his guide. Johann Friedrich's aigrette of heron feathers, his Raigerbusch, was adorned with a diamond feather and a ribbon of twelve diamonds; Hainhofer established that it was said to have cost the duke 2,00o florins. ${ }^{111}$

Württemberg continued to position itself as a distinguished, international, Anglophone Protestant court, with new forms of dress and an interest in new types

106 Ludwig Krapf and Christian Wagenknecht, eds., Stuttgarter Hoffeste: Texte und Materialien zur höfischen Repräsentation im frühen 17. Jahrhundert, vol. 2 (Tübingen: Max Niemeyer, 1979), 118-122, this is ignored in Schmidt's focus on patriotism.

107 Ibid., 2:100.

108 Ibid., 100-103.

109 Ibid., 331, 342.

110 Ibid., 328.

111 Ibid., 329 . 
of craft and learning. The fascination with English dress, which had already appealed to Frederick, went so far that Prince Lewis-Frederic of Württemberg himself dressed up as an English lady. The prince had even mastered riding side-saddle. He and his two companions distinguished themselves through their bare necks (instead of wearing more restricting high-necked collars and ruffs) and wore gowns made from

white satin from China (embroidered with) with red and blew flowers, their petticoats of a sea-greene colour: they had in their hand blacke fannes (fans), in summe they were right like English Ladies, sitting a side as ladies are wont to ride and naming themselves by borrowing English names. ${ }^{112}$

The men attired as ladies Darby, Winchester, and Pembroke announced, no less, that "Womankind doe excel mankind as farre as heaven excelleth earth" - women excel men as far as heaven excels earth. ${ }^{113}$ Such expertise continued to manifest itself in alchemical and medical experiment and experience, for the benefit of mankind. Hainhofer thus visited the two laboratories of the ducal pharmacy, which traditionally were operated by the duchess and other women, and were situated next to the rooms for the princess, her ladies, and the smaller and older children. ${ }^{114}$

He also visited the cabinet of curiosities, noting that it contained many "pieces of Schwegler's featherwork." ${ }^{115}$ Schwegler was a prized artist who fixed feathers onto wax miniatures of birds and supplied the Stuttgart as well as other courts with artificial bird houses or whole miniature farmyards. ${ }^{116}$ The art agent next repeated a visit to one of the most ambitious of Frederick's and John Frederick's cameralist projects, the "silk house," which continued to operate until much of Württemberg was devastated after the battle of Nördlingen during the Thirty Years' War, in 1634. Hainhofer admired the local production of silk, which had been grown in Württemberg and spun and manufactured in Stuttgart into rich velvets and other silks in order to alleviate the burden of costly imports on the population. ${ }^{117}$ This highlighted the virtuous ingenuity of craftspeople who had been lured to Württemberg from Italy and Geneva. ${ }^{118}$

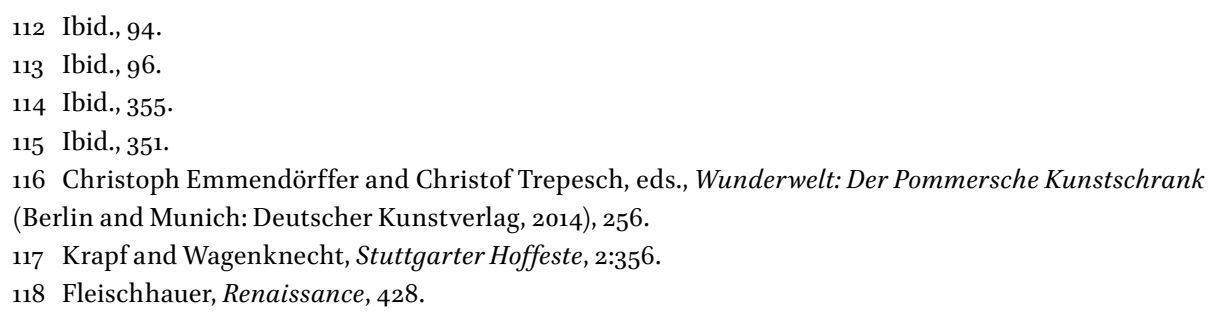


Rudolf Weckherlin dedicated his account of the baptism to Elizabeth Stuart. ${ }^{119}$ "My soul," he enthused, "was amazed with marvell: mine eyes did dazzle: and all my senses were overwhelmed by the majestie, beautie, richesse, and magnificence of those brave Princeses, Princes, Ladies, Lords and Knights." ${ }^{\prime 20}$ Expenditure was once more vast - in 1616-18, more than 7,00o florins were paid to artisans just for work carried out to prepare the celebrations. ${ }^{121}$ High-quality feathers continued to be costly: in 1618, Jacob Unangst, the Federschmucker, was paid $5_{2}^{2}$ florins for just "15 feathers, of different colours." ${ }^{\text {122 }}$

Eyes were "fed" with such pleasant sensations, and Weckherlin thus detailed the apparel of those who partook in the elaborate masque. Here were "bravely apparelled" ancient Romans, "all in white satin, covered with gold and silver, their helmets garnished with great bunches of red, yellow, blew, and white feathers." ${ }^{\prime 23}$ An Indian with a "fair cloke of coloured feathers" and a hat made of feathers jumped out of a giant head. ${ }^{124}$ Trojan knights appeared, their "head peeces glistering of gold and silver, and covered with great yellow and white feathers."125 Hector sported a golden helmet on which floated a green and white feather panache. Mercurius and Apollo were adorned with "great bunches of red, white, and yellow feathers," while a Trojan monarch wore a golden helmet "where did waver upon a plume of manie faire colours." ${ }^{\prime 26}$

Frederick V of the Palatinate was the most noble guest at the baptism and appeared as a dazzling Scipio Africanus, a conqueror whose "sumptuous helmet was over-shadowed by a great wavering bunch of red and white feathers." His horse despised the ground and bore "himself up by his own courage, might and ostentation in a higher element." This was an approximate translation of the German text and emphasized the understanding that feathers and their translucent adornments, such as spangles - small, gilded metal-plates attached to feathers - or jewellery and their movement, instantiated an awe-inspiring, masterful moment of engagement with air as a higher element than earth, performing triumphant magnificence as moral superiority:

119 Ibid., 333f. and through the close diplomatic ties forged between Stuttgart and London, Weckherlin later came to serve the English Crown, arranging masques for Queen Henrietta Maria.

120 Krapf and Wagenknecht, Stuttgarter Hoffeste, 1:18f.

121 HStAS, A 256, vol. 103, 39or, two entries for over 4,000 florins, which summarize the costs and thus make it impossible to gauge how much was paid for feathers and featherwork. Further bills came in during the following year - see for instance a bill for twelve ballet outfits of 142 florins, vol. 104, 338v and 389v, summary costs of 1,884 florins.

122 HStAS, A 256, vol. 104, 389r.

123 Krapf and Wagenknecht, Stuttgarter Hoffeste, 1:20-23.

124 Ibid., 24f.

125 Ibid., 32 f.

126 Ibid., 34-36. 
His steed, recognizing and appreciating, as it were, his superhuman encumbrance, kept rearing up and haughtily stamping the earth, prancing with his gleaming adornments and shaking his flying plumes of feathers in the air.

Sein hengst, erkennend gleichsam und schätzend seine übermenschliche bürde, erhub sich derselbingen ohn ablaß und stampffte verächtlich die erden, prachtierte mit seiner schimmernden zier und fliegenden federbuschen in dem luft. ${ }^{127}$

Horses were, of course, likewise adorned with feathers, and their quality was repeatedly emphasized as they could be described as "high feathers," ${ }^{28}$ or "great peacock-feather panaches" to accentuate pride and fallibility. ${ }^{129}$

The running of the ring caused more sensation. Nothing, wrote Weckherlin,

could be seene round [...], but silver, gold, jewels, flowers, feathers, banners, launces and pennons of all colours. The splendour did dazzle the eyes of the beholders, and the richesse did ravish their minds.

This complemented, rather than exactly translated, the German:

Man sahe nichts innerhalb den schrancken ganz herumb, dan silber, gold, edelgestein, und gestickte klaider glänzen, und allerley blumen, federn und fahnen inder luft schweben. Möniglich war mit wunder verzuckt ab dem pomp all dieser newheiten.

Within the ring one saw nought but silver, gold, precious stones, and shimmering embroidered garments, and all manner of flowers, feathers and pennants floating in the air. Many were dazzled by wonderment at the pomp of all these novelties. ${ }^{130}$

The materials and dramaturgy used in the tournament were once more designed to emanate affective transformations in the audience through animated accessories. The "graceful managing" of "bodily behaviour" induced astonishment, awe, and dread through demonstrations of power, as much as hope and pleasure through acts of mercy. ${ }^{131}$

127 Ibid., 48f, my emphasis, and: the beauty of the horses increased his "magnificence and wonder."

128 Ibid., 60.

129 Ibid., 67, 70 .

130 Ibid., $86 \mathrm{f}$.

131 Ibid., 88. 


\section{Conclusion}

Duke Frederick's parading as America did not just remain a fleeting vision to present the splendours of his cabinet of curiosities and stage his magnificence. Since 1595, Frederick's court painter and sculptors had worked on a major new portal for the court. It now faced the city of Stuttgart and showed Frederick's and his wife Sibylla von Anhalt's coats of arms surrounded by several life-sized standing and lying "Indian" figures, which represented the 1599 procession. ${ }^{132}$ Frederick's interest in the New World was thus commemorated as public art - Frischlin's description declared that in Stuttgart the new portal could be seen from "every where" and all Württembergers needed to understand its significance. ${ }^{133}$

The entertainment, therefore, underlines the necessity to re-orient our understanding of Lutheran court culture in the confessional age. It cannot be understood as insular, frozen in time, or solely as dominated by an affective atmosphere generated by apocalyptic Lutheran sermons. Rather, Frederick used feathers as cultural material and commemorated their use on the gate for all Württembergers in order to propagate the benefits of innovation, empirical knowledge, craft, and cultural exchange. An account of a 1596 entertainment at the Protestant court in Kassel had already innovated by staging America as one among the continents through the use of featherwork, and a printed report followed de Bry's condemnation of Spanish atrocities. ${ }^{134}$ A positive depiction of America as a sister continent thus served as a Protestant programme that fused with a positive vision of global trade and, as the example of the Calvinist Johann Moritz of Nassau Siegen - who had been educated at the Kassel court - would soon bear out in Brazil, the possibility of expanding empire. ${ }^{135}$ The completion of a building programme in 1599 , which

132 Fleischhauer, Renaissance, 274; Frischlin, Auffzug, 44: "Darauff folgt Herzog Friderich/ Der durchleuchtig ließ sehen sich/ Mit seim Auffzug in solcher Gstalt/ Wie auff diß Fürsten Hoffthor gmahlt/ Von neuwen Königlichen Portall/ Zu Stuttgart sihst dus uberall/ Oder wie ich da beschreiben will/ Merkt auff ihr Würtenberger/still" (in translation: Duke Frederick followed/ His Highness let himself be seen/ In an array such as/ that painted on the princely court gate/ of the new Royal Portal/ At Stuttgart you can see it from everywhere/ Or as I choose to describe it/ Württembergers take note).

133 Archival evidence likewise suggests that a new portal was built. On the function of masques in Germany see Schnitzer, Höfische Maskeraden, $358 \mathrm{f}$.

134 Hesse, Kunstkammer, 163; Brozinski and Schweikhart, Wilhelm Dilich, for the positive representation of ingenuity trained/cultivated through craftsmanship to which artefacts testify, transforming humans through acquired skill. For the history of European understanding that practice develops mental as well as manual ability and is therefore a liberal rather than mechanical art, see Marieke M. A. Hendriksen, “'Art and Technique Always Balance the Scale': German Philosophies of Sensory Perception, Taste, and Art Criticism, and the Rise of the Term Technik, ca. 1735-ca. 1835," History of Humanities 2, no. 1 (2017): 201-219.

135 Featherwork from Brazil remained of great value as diplomatic gifts for Protestant leaders during the seventeenth century, after Johann Moritz's return, see Françozo, "Beyond the Kunstkammer," 120. 
erased eleven civic houses in order to create more space for the ducal castle and associated squares, buildings, gardens, and gates, along with Frischlin's account, Cellius's poem, Rathgeb's book, and the images of the 1599 entertainment, all served to bolster a vision of Württemberg's leadership towards a future for which openness to innovation, travel, different cultures, and modern foreign languages in an interconnected global world was vital. ${ }^{136}$ It was a visual as much as material act to transform the mindsets of the estates and population who seemed rooted in their localities and local needs. ${ }^{137}$ Württemberg itself was a leader among the Protestant nations. Featherwork could be staged as an important idiom of this luminous leadership to set off new affective atmospheres. ${ }^{138}$ Objects, vision, and touch were thus increasingly integrated into a concept of political rhetoric that opened up to "new possibilities" through performances. These entertainments were designed to persuade and appeal to reason as much as to transform affects from ungoverned passions into eloquent moral, subtle, and graceful sentiments. ${ }^{139}$ The 1599 entertainment and John Frederick's Protestant Union festivals can in this sense be read as outstanding attempts to animate and transform affects in the body politic. In Stuttgart, these affective atmospheres sought, above all, to stabilize optimism about future discoveries and territorial development, as well as the strength of the Protestant Union on the eve of the Thirty Years' War. ${ }^{140}$

136 See also Christadler, "Indigenous Skins," 24.

137 The core of this interpretation is also supported by Fleischhauer, Renaissance; on the building programme, the role of clothing, dance, festivities, and food see also Nicole Bickhoff, "'Gott kann der Welschen pracht nicht leiden'."

138 Andreas Reckwitz, "Affective Spaces: A Praxeological Outlook," Rethinking History 16, no. 2 (2012): $241-258$.

139 See the important work by Mark Greengrass, Governing Passions: Peace and Reform in the French King-

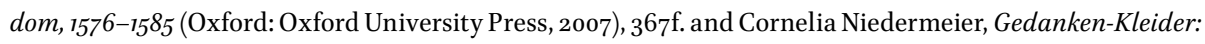
Die Allegorisierung des Körpers in Gesellschaft und Theater des 17.Jahrhunderts (Vienna: Universitätsverlag, 2000), 48.

140 For the definition of the term affective culture and habitus see Andreas Reckwitz's pioneering essay, "Affective Spaces," 253-255; on the political importance of the pioneering Protestant Union festivals in Württemberg see Watanabe-O'Kelly, Triumphall Shews. 


\section{Bibliography}

\section{Unpublished Primary Sources}

Landesarchiv Baden-Württemberg, Hauptstaatsarchiv Stuttgart (HStAS)

A 20a, vol. 4

A 256 , vols. $81,82,83,85,86,87,88,97,103,104$

\section{Published Primary Sources}

Bornitz, Jakob. De Rerum Sufficientia in Rep. \& Civitate procuranda [...]. Frankfurt-am-Main: Tampachius and Weissius, 1625 .

Cellius, Erhard. Wahrhaffte Beschreibung Zweyer Raisen. Tübingen: Cellische Truckerey, 1603 .

Dilich, Wilhelm. Historische Beschreibung der Fürstlichen KindstauffFräwlein Elisabetha zu Hessen ... Welche im Augusto dess 159 6. Jahrs zu Cassel gehalten worden. Kassel, 1598.

Frischlin, Jakob. Beschreibung deßfürstlichen Apparatus, königlichen Auffzugs, heroischen Ingressus und herrlicher Pomp und Solennittet. Frankfurt-am-Main: Joachim Brathering, 1602. http://digital.slub-dresden.de/werkansicht/dlf/65017/1/.

Rathgeb, Jacob. Kurtze und Warhaffte Beschreibung der Badenfahrt [...]. Tübingen: Cellius, 1602.

\section{Secondary Literature}

Bickhoff, Nicole. “'Gott kann der Welschen pracht nicht leiden': Hof- und Festkultur unter Herzog Friedrich I. von Württemberg.” In Hofkultur um 16oo: Die Hofmusik Herzog Friedrichs I. von Württemberg und ihr kulturelles Umfeld, edited by Joachim Kremer, Sönke Lorenz, and Peter Rückert, 73-94. Sigmaringen: Thorbecke, 2010.

Boogart, Ernst van den. Civil and Corrupt Asia: Image and Text in the Itinerario and the Icones ofJan Huygens van Linschoten. Chicago, IL: Chicago University Press, 2003.

Boone, Elizabeth H. "Seeking Indianness: Christoph Weiditz, the Aztecs and Feathered Amerindians." Colonial American Review 26, no. 1 (2017): 39-51.

Bredekamp, Horst. Image Acts: A Systematic Approach to Visual Agency. Berlin and Boston, MA: De Gruyter, 2018.

Brozinski, Hartmut, and Günther Schweikhart, eds. Wilhelm Dilich:Ritterspiele anno 1596. Kassel: Wenderoth, 1986.

Bujok, Elke. Neue Welten in europäischen Sammlungen: Africana und Americana in Kunstkammern bis 1670. Berlin: Reimer, 2004.

Buono, AmyJ. “Their Treasures Are the Feathers of Birds': Tupinambá Featherwork and the Image of America." In Images Take Flight: Feather Art in Mexico and Europe 1400-1700, 
edited by Alessandra Russo, Gerhard Wolf, and Diane Fane, 178-189. Munich: Hirmer, 2015 .

Buono, Amy J. "Representing the Tupinambá and the Brazilwood Trade in Sixteenth-Century Rouen." In Cultural Exchange between Brazil and France, edited by Regina R. Felix and Scott D. Juall, 19-34. West Lafayette, IN: Purdue University Press, 2016.

Cavallo, Sandra. "Health, Air and Material Culture in the Early Modern Italian Domestic Environment." Social History of Medicine 29, no. 4 (2016): 695-716.

Cavallo, Sandra, and Tessa Storey. Healthy Living in Late Renaissance Italy. Oxford: Oxford University Press, 2013.

Christadler, Maike. "Indigenous Skins: Indian Costume at the Court of Württemberg." In Visual Representations of Native Americans: Transnational Contexts and Perspectives, edited by Karsten Fritz, 13-28. Heidelberg: Universitätsverlag, 2012.

Cook, Harold. Matters of Exchange: Commerce, Medicine, and Science in the Dutch Golden Age. New Haven, CT: Yale University Press, 2007.

Die Kunstkammer der Herzöge von Württemberg: Bestand - Geschichte - Kontext, 3 vols., exh. cat. Ulm: Jan Thorbecke, 2017.

Emmendörffer, Christoph, and Christof Trepesch, eds. Wunderwelt: Der Pommersche Kunstschrank. Berlin and Munich: Deutscher Kunstverlag, 2014.

Fleischhauer, Werner. Renaissance im Herzogtum Württemberg. Stuttgart: Kohlhammer, 1971. Fleischhauer, Werner. Die Geschichte der Kunstkammer der Herzöge von Württemberg in Stuttgart. Stuttgart: Kohlhammer, 1976.

Françozo, Mariana. "Beyond the Kunstkammer: Brazilian Featherwork in Early Modern Europe." In The Global Lives of Things: Material Culture of Connections in the Early Modern World, edited by Anne Gerritsen and Giorgio Riello, 105-127. London: Routledge, 2016.

Gerritsen, Anne, and Giorgio Riello, eds. The Global Lives of Things: The Material Culture of Connections in the Early Modern World. London and New York: Routledge, 2016.

Greengrass, Mark. Governing Passions: Peace and Reform in the French Kingdom, 1576-1585. Oxford: Oxford University Press, 2007.

Grube, Walter. Der Stuttgarter Landtag 1457-1957: Von den Landständen zum demokratischen Parlament. Stuttgart: Ernst Klett, 1957.

Hanß, Stefan. Court and Material Culture in Early Modern Germany: A Sourcebook on the Duke of Württemberg's Payments to Artisans, Stuttgart, 1592-1628. Amsterdam: Amsterdam University Press, forthcoming.

Hendriksen, Marieke M. A. “'Art and Technique Always Balance the Scale': German Philosophies of Sensory Perception, Taste, and Art Criticism, and the Rise of the Term Technik, ca. 1735-ca. 1835." History of Humanities 2, no. 1 (2017): 201-219.

Hesse, Sabine. "Die Neue Welt in Stuttgart: Die Kunstkammer Herzog Friedrich I. und der Aufzug zum Ringrennen am 25. Februar 1599." In Hofkultur um 16oo: Die Hofmusik Herzog Friedrichs I. von Württemberg und ihr kulturelles Umfeld, edited by Joachim Kremer, Sönke Lorenz, and Peter Rückert, 139-165. Sigmaringen: Thorbecke, 2010. 
Hunger, F. W. T. "Bernardus Paludanus (Barent ten Broeke) 1550-1633: Zijn verzamelingen en zijn werk." In Itinerario: voyage ofte schipvaert van Jan Huygen van Linschoten naer Oost ofte Portugels Indien 1579-1592, edited by C. P. Burger and F. Hunger, vol. 3, 249-268. 's-Gravenhage: Martinus Nijhoff, 1934.

Jachmann, Julian. “... in Ritterspieln und hohem Gebreng fremder nationen erfahren: Feste und Turniere der Fugger im frühneuzeitlichen Augsburg.” In Herrschaft - Architektur Raum: Festschrift für Ulrich Schütte zum 6o. Geburtstag, edited by Stephanie Hahn and Michael H. Sprenger, 261-275. Berlin: Lukas Verlag, 2008.

Kaufmann, Thomas. Dreißigjähriger Krieg und Westfälischer Friede. Kirchengeschichtliche Studien zur lutherischen Konfessionskultur. Tübingen: Mohr Siebeck, 1998.

Kaufmann, Thomas. Konfession und Kultur: lutherischer Protestantismus in der zweiten Hälfte des Reformationsjahrhunderts. Tübingen: Mohr Siebeck, 2006.

Keller, Vera. Knowledge and the Public Interest, 1575-1725. Cambridge: Cambridge University Press, 2015 .

Kessler, Herbert L. Seeing Medieval Art. Toronto: University of Toronto Press, 2011.

Korn, Melanie. Die zwei Federschilde des Landesmuseums Württemberg. Stuttgart, April 2015, unpublished conservation report.

Krapf, Ludwig, and Christian Wagenknecht, eds. Stuttgarter Hoffeste: Texte und Materialien zur höfischen Repräsentation im frühen 17.Jahrhundert, vol. 2. Tübingen: Max Niemeyer, 1979.

Krekler, Ingeborg. Die Handschriften der Württembergischen Landesbibliothek Stuttgart, vol. 3: Stammbücher bis 1625. Wiesbaden: Harrassowitz, 1999.

Kuriyama, Shigehisa. The Expressiveness of the Body and the Divergence of Greek and Chinese Medicine. New York: Zone Books, 1999.

Leppin, Volker. Antichrist und Jüngster Tag: Das Profil apokalyptischer Flugschriftenpublizistik im deutschen Luthertum 1548-1618. Gütersloh: Mohn, 1992.

Maritz, Regine. "Gender as a Resource of Power at the Early Modern Court of Württemberg, c. 1580-1630." PhD diss., University of Cambridge, 2018.

Markey, Lia. Imagining the Americas in Medici Florence. University Park, PA: Pennsylvania State University Press, 2016.

Meadow, Mark. "Merchants and Marvels: Hans Jakob Fugger and the Origins of the Wunderkammer." In Merchants \& Marvels: Commerce, Science and Art in Early Modern Europe, edited by Pamela H. Smith and Paula Findlen, 182-200. New York: Routledge, 2002.

Moran, Bruce T. The Alchemical World of the German Court: Occult Philosophy and Chemical Medicine in the Circle of Moritz of Hessen (1572-1632). Stuttgart: Steiner, 1991.

Newman, William R. "From Alchemy to 'Chymistry'.” In The Cambridge History of Science, vol. 3, edited by Katharine Park and Lorraine Daston, 497-517. Cambridge: Cambridge University Press, 2006.

Niedermeier, Cornelia. Gedanken-Kleider: Die Allegorisierung des Körpers in Gesellschaft und Theater des 17. Jahrhunderts. Vienna: Universitätsverlag, 2000. 
Nummedal, Tara. Alchemy and Authority in the Holy Roman Empire. Chicago, IL: Chicago University Press, 2008.

Ognois, Laure. "Dass ein Cavallier seinen Dienst nicht besser kan anwenden, als denselben dem Vaterland zu nutzen den Unirten zu praesentieren: Politische Instrumentalisierung eines christlichen Ereignisses? Die Festtaufe Friedrich von Württembergs im Jahre 1616." In Union und Liga 1608, 16og: Konfessionelle Bündnisse im Reich - Weichenstellung zum Religionskrieg, edited by Albrecht Ernst and Anton Schindling, 227-262. Stuttgart: Kohlhammer, 2010.

Oster, Carolin. Die Farben höfischer Körper: Farbattributierung und höfische Identität in mittelhochdeutschen Artus- und Tristanromanen. Berlin: De Gruyter, 2012.

Pieper, Renate. Die Vermittlung einer Neuen Welt: Amerika im nachrichtennetz des Habsburgischen Imperiums 1493-1598. Mainz: von Zabern, 2000.

Reckwitz, Andreas. "Affective Spaces: A Praxeological Outlook." Rethinking History 16, no. 2 (2012): 241-258.

Roller, Hans-Ulrich. Der Nürnberger Schembartlauf: Studien zum Fest- und Maskenwesen des späten Mittelalters. Tübingen: Tübinger Vereinigung für Volkskunde, 1965.

Rublack, Ulinka. The Astronomer and the Witch:Johannes Kepler's Fight for His Mother. Oxford: Oxford University Press, 2015.

Rublack, Ulinka. "Renaissance Dress, Cultures of Making, and the Period Eye." West 86th: AJournal of Decorative Arts, Design History, and Material Culture 23 (2016): 6-34.

Rublack, Ulinka. "Befeathering the European: The Matter of Feathers in the Material Renaissance.” The American Historical Review 126, no. 1 (March 2021): 19-53, https:// doi.org/10.1093/ahr/rhaboo6.

Russo, Alessandra. "Cortés's Objects and the Idea of New Spain: Inventories as Spatial Narratives." Journal of the History of Collections 23, no. 2 (2011): 229-252.

Russo, Alessandra, Gerhard Wolf, and Diana Fane, eds. Images Take Flight: Feather Art in Mexico and Europe, 1400-170o. Munich: Hirmer, 2015.

Sauer, Paul. Herzog Friedrich I. von Württemberg 1557-1608: Ungestümer Reformer und weltgewandter Autokrat. Munich: Deutsche Verlags-Anstalt, 2003.

Schmidt, Alexander. Vaterlandsliebe und Religionskonflikt: Politische Diskurse im Alten Reich (1555-1648). Leiden and Boston, MA: Brill, 2007.

Schnitzer, Claudia. Höfische Maskeraden: Funktion und Ausstattung von Verkleidungsdivertissements an deutschen Höfen der frühen Neuzeit. Tübingen: Niemeyer, 1999.

Schulze, Winfried. "Vom Gemeinnutz zum Eigennutz: Über den Normenwandel in der ständischen Gesellschaft der Frühen Neuzeit." Historische Zeitschrift 243 (1986): 591-626.

Smith, Pamela H., and Paula Findlen, eds. Merchants \& Marvels: Commerce, Science and Art in Early Modern Europe. New York: Routledge, 2002.

Swan, Claudia. "Exotica on the Move: Birds of Paradise in Early Modern Holland." Art History 38 , no. 4 (2015): 621-635. 
Trepp, Anne-Charlott. "Natural Order and Divine Salvation: Protestant Conceptions in Early Modern Germany (1550-1750)." In Natural Law and Laws of Nature in Early Modern Europe:Jurisprudence, Theology, Moral, and Natural Philosophy, edited by Lorraine Daston and Michael Stolleis, 123-142. Aldershot: Ashgate, 2008.

Van Eck, Caroline. Classical Rhetoric and the Visual Arts in Early Modern Europe. Cambridge: Cambridge University Press, 2007.

Van Gelder, Roelof. "Paradisvogels in Enkhuizen: De relatie tussen Van Linschoten en Bernardus Paludanus." In Souffrir pour parvenir: De wereldd van Jan Huygen van Linschoten, edited by Roelof van Gelder, 30-50. Haarlem: Uitg. Arcadia, 1998.

Van Groesen, Michiel. The Representation of the Overseas World in the De Bry Collection of Voyages (1590-1634). Leiden and Boston, MA: Brill, 2008.

Warburg, Aby. “Die Theaterkostüme für die Intermedien.” In Aby Warburg: Werke in einem Band, edited by Martin Trend, Sigrid Weigel, and Perdita Ludwig, 124-167. Frankfurtam-Main: Suhrkamp, 2010.

Warburg, Aby. “Sandro Botticellis 'Geburt der Venus' und 'Frühling'.” In Aby Warburg: Werke in einem Band, edited by Martin Trend, Sigrid Weigel, and Perdita Ludwig, $3^{2-38}$. Frankfurt-am-Main: Suhrkamp, 2010.

Watanabe-O'Kelly, Helen. Triumphall Shews: Tournaments at German-Speaking Courts in their European Context, 156o-1730. Berlin: Mann Verlag, 1992.

Wintroub, Michael. A Savage Mirror: Power, Identity, and Knowledge in Early Modern France. Stanford, CA: Stanford University Press, 2006.

Zander-Seidel, Jutta. Textiler Hausrat: Kleidung und Haustextilien in Nürnberg von 1500-1650. Munich: Deutscher Kunstverlag, 1990.

\section{About the Author}

Ulinka Rublack is Professor of Early Modern History at Cambridge University and Fellow of St John's College. In addition to research on Reformation and on gender history, Rublack specializes in the history of dress. Her books on this subject include Dressing Up: Cultural Identity in Renaissance Europe (Oxford University Press, 2010). 
